\title{
Mimari Detaylandirma
}

Eğitimi Bağlamında "Ince Yapı Bilgisi"

\section{Dersinin Analizi}

Ömer Ş. Deniz, Özlem Eren, Savaş Ekinci, Bahar Başarır, Lory Zakar, Görkem Arslan, Havva Aksel

Mimar Sinan Güzel Sanatlar Üniversitesi,

Mimarlık Fakültesi, Mimarlık Bölümü

\section{Giris}

Mimari tasarımın bir parçası olan "Mimari Detay", uygulanacak bir tasarımın en gerçek çizgilerini oluşturur. Binanın yaşam süresince tüm iç ve dış etkenlere karşı vereceği başarılı mücadelenin temel çözümlerini detay çizimleri belirler. Doğru bir mimari detay çözümü, yapı malzemelerinin, yapım teknolojilerinin, gereksinimlerin ve olanakların iyi bilinip gerçekçi şekilde değerlendirilmesini gerektirir. Mimari detay çözümleme (mimari detaylandırma) malzemelerin, bileşenlerin ve elemanların her detay durumuna göre değişebilecek işlevsel ve estetik amaçlar doğrultusunda bir araya getirilme sanatıdır. Bu nedenle mimari detaylandırmada bilgi ve tecrübe önemlidir (Frascari, 1984; Şahinler ve Klzıl, 2004).

Günümüzde üniversitelerde mimari detaylandırma eğitimine ayrılan zaman, diğer tasarım derslerine ve konularına göre çok daha az ve yetersiz durumdadır (Ballast, 2009). Mimari detay sorunları, üniversitelerdeki ilgili derslerde analitik yöntemlerle kazanılması gereken bilgi birikimi ve detaylandırma becerisi yerine, mimari proje derslerinde ve öğrenim sonrası mesleki çalışmalarda hazır standart detayların, firma detaylarının veya benzer proje detaylarının kopyalanması yoluyla, diğer bir deyişle deneme yanılma (kulaktan dolma) yöntemlerle çözümlenmeye çalışılmaktadır. Oysa her alanda olduğu gibi mimari detaylandırma alanında da bilgi birikimi, sorun çözme ve öneri geliştirme becerisi öncelikle üniversite eğitim sürecinde kazanılmalı, meslek yaşamında ise bu kazanımlar mesleki uygulamalar ve tecrübelerle geliştirilebilmelidir. Bu nedenle mimarlık öğrencilerine detaylandırma becerisinin kazandırılmasını sağlayacak, uygun yöntemler içeren derslere gereksinim vardır (Cheng ve Schierle, 2006).

Üniversitelerdeki mevcut mimari detaylandırma eğitimi çoğunlukla, detayların nasıl çözümlendiğine dair sistematik bir analize yer vermeyen hazır detay koleksiyonlarından, birbirinden ayrı derinlemesine incelenmiş çeşitli detay konularından, diğer projeler için rehber niteliği taşımayan örnek durum incelemelerinden veya öğrencilerin anlamakta güçlük çektiği soyut saf teorilerden oluşmaktadır. Meslek yaşamında karşılaşabileceği birçok karmaşık mimari detay sorunuyla baş edebilmesi ve tecrübeli bir detay tasarımcısı olabilmesi için, bir mimarlık öğrencisinin, hem binayı oluşturan yapı bileşeni ve elemanları hakkında bilgi birikimi oluşturması hem de bu bileșen ve elemanların kendi sistem kompozisyonlarında ve birleşim noktası konfigürasyonlarında detay çözümü becerisi kazanması gerekir (Emmit vd., 2004).
Öz

Bu çalışma, mimari detaylandırma eğitimi bağlamında, MSGSÜ Mimarlık Fakültesi Mimarlık Bölümü'nde verilmekte olan MIM 316 İnce Yapı Bilgisi dersinin analiz edilip, işleyiş performansının değerlendirilmesini ve sorunlar için öneriler geliştirilmesini amaçlamaktadır. Bu doğrultuda önce, hazırlanan ders programı genel hatlarıyla açıklanmıştır. Hazırlanan programa göre İnce Yapı Bilgisi dersi, birbirini tamamlayan "Teorik ve Uygulamalı" derslerle yürütülür. Teorik derslerde, mimari detaylandırma ve detay tasarımı konusunda belirli teorik bilgiler anlatılır. Uygulamalı derslerde ise öğrenci, anlatılan teorik bilgileri pekiştirmek ve detaylandırma becerisi kazanmak amacıyla, belirlenen bir konuya ilişkin uygulama çalışmaları yapar. Ders programının izlendiği 2015-2016 Bahar Dönemi'nde, öğrencilerin her hafta gerçekleştirdiği uygulama çalışmaları, ders programında hedeflenen "Dersin Öğrenme Kazanımları” kapsamında ve uygulama konularına göre belirlenen kriterler doğrultusunda değerlendirilmiştir. $\mathrm{Bu}$ değerlendirmelerde, öğrencilerin çoğunlukla yaptığı hatalar ve hata yapan öğrenci sayıları belirlenmiştir. Böylece öğrencilerin her hafta anlatılan ders konusunu öğrenme durumları sınanarak, dersin içeriğindeki ve işleyişindeki sorunlar saptanmaya çalışılmıştır. Daha sonra performans değerlendirmesinde ortaya çıkarılan sonuçlar yorumlanarak, hem dersin içeriğinde hem de öğretilme yöntemlerinde eksik ve olumsuz taraflar açıklanmış ve iyileştirme önerileri sunulmuştur.

\section{Abstract}

This study aims to analyze the efficiency of MIM 316 Architectural Detailing (Ince Yapr Bilgisi) course being conducted in Faculty of Architecture in MSFAU, in the context of architectural detailing training. As a result of operation performance evaluation of the course, development of suggestions for problems is targeted. Primarily, the course schedule, consisting of theoretical end practical parts, is generally explained. In the theoretical part of the course, students are presented with theoretical information about architectural detailing and detail design. The complementary practice part of the course, requires students to make detailed drawings on determined topic in order to intensify their theoretical knowledge and to gain the ability of detailing. Course data, practice drawings of 2015-16 Fall Semester is evaluated in the context of 'Course Learning Outcomes' and according to criteria determined upon practice topics. Most common mistakes and number of mistakes of students are identified. Learning ratio of students are measured by these weekly results. Problems in the operation and content of the course are seeked. Outputs of performance evaluation are discussed, deficiencies and weaknesses in the content and teaching methods are explained and suggestions for amelioration are presented.

Anahtar Kelimeler: İnce Yap1, Mimari Detaylandırma, Detay Tasarımı, Mimarlık Eğitimi, Eğitim Değerlendirme

Keywords Architectural Detailing, Detail Design, Architectural Education, Educational Evaluation 
MSGSÜ, Türkiye'de bir ders kapsamında mimari detaylandırma eğitimi veren en eski üniversite kurumlarından biridir. 1941 yılında, o dönemki adı Güzel Sanatlar Akademisi olan bu kurumun Mimarlık Bölümü'nde İnce Yapı adıyla kaplama ve doğrama konularını ele alan ve yapı detaylarının öğretildiği bir kürsü kurulmuştur (Eldem, 1967). Bu çalıșmada, böyle bir kurumda uzun yıllarda kazanılmış olan mimari detaylandırma eğitim birikiminin ve tecrübesinin süregitmesi için, dersin yeni gelişmeler ve değişiklikler karşısında temel hedefleri ve ilkelerinin korunarak güncellenmesi, ortaya çıkan sorunların, eksiklerin ve yetersizliklerin giderilmesi hedeflenmiștir. Bu nedenle çalışmada, MSGSÜ Mimarlık Fakültesi Mimarlık Bölümü'nde verilmekte olan ve mimari detaylandırma konularını içeren MIM 316 İnce Yapı Bilgisi dersi kapsamında hazırlanan ders programı analiz edilmiş ve bu programın uygulandığ 1 bir eğitim döneminde dersin öğrenme çıktılarına göre işleyiş performansı değerlendirilmiștir. Daha sonra performans değerlendirmesinde ortaya çıarılan sonuçlar yorumlanarak, hem dersin içeriğinde hem de öğretilme yöntemlerinde eksik ve olumsuz taraflar açıklanmış ve iyileştirme önerileri sunulmuştur.

\section{MIM 316 İnce Yapı Bilgisi Dersi}

MIM 316 İnce Yapı Bilgisi dersinin temel amacı, ögrencilere binayı oluşturan çeşitli bileşen ve elemanların tasarım ve yapım ilkelerini öğretmek, detay tasarım ve çizim becerisi kazandırmaktır. Ders genel olarak iç bölme sistemi ve dış kabuk sistemi konularını içerir. İç bölme sistemi kapsamında döşeme kaplamaları, iç duvar kaplamaları, iç bölme duvarları, tavan kaplamaları ve iç kapılar, dış kabuk sistemi kapsamında ise dış duvar kaplamaları, dış kapılar, pencereler, çatı kaplamaları ve giydirme cepheler odak konular olarak belirlenmiştir. Ders konularını oluşturan yapı malzeme, bileşen ve elemanları, bütünleştikleri diğer bileşen ve elemanlarla birlikte detay ölçeğinde ele alınır. İnce Yapı Bilgisi dersi, birbirini tamamlayan Teorik ve Uygulamalı derslerle yürütülür. Teorik derslerde, programdaki konulara ilişkin teorik bilgiler anlatılır. Uygulamalı derslerde ise öğrenciler, teorik derslerde anlatılan konulara ilişkin hazırlanan bir soruyu uygulama atölyesinde öğretim elemanlarının denetiminde çözümleyerek çizimini yapar.

MIM 316 İnce Yapı Bilgisi dersi bir dönemlik (14 haftalı) eğitim süresine sahiptir. $\mathrm{Bu}$ kısıtlı süre içinde öğrencilere mimari detaylandırma ile ilgili tüm konuların ve detayların anlatılması ve öğretilmesi olanaksız olduğu için, ders programında çok geniş bir yelpazeden seçilen belirli konular yer alır. Bu nedenle derslerde malzeme ve teknolojilerin yanı sıra, birçok farklı konu için geçerli olabilecek temel detaylandırma (detay tasarımı) ilkeleri ve yöntemleri üzerinde durulur. Anlatılan detay çözümleri birer sonuç olarak değil, mimari detaylandırma ilke ve yöntemlerini yansıtan örnekler biçiminde sunulur. Mimari detay sorunlarının tartışılmasını, ilkelerin ve çözüm önerilerinin geliştirilmesini yöntem olarak benimseyen bu derste, klasik ve kolay anlaşılabilir malzeme, teknoloji ve detaylar öncelikle ele alınır. Ahşap, detay çözümlerinde kolay anlaşılması ve kolaylıkla biçimlendirilme olanakları sağlaması nedeniyle, derslerde en fazla üzerinde çalışılan alternatif malzemedir. Detay çözümlerinde ahşabın dışında başka malzemelerin de kullanılabileceği ve belirlenen detaylandırma ilkeleri doğrultusunda farklı malzemelerle farklı detay alternatiflerinin de üretilebileceği derslerde ayrıca vurgulanır.

2015-2016 Bahar Döneminde MIM 316 İnce Yapı Bilgisi dersinin 14 haftalık ders programı konuları genel başlıklarına göre şu şekilde belirlenmiştir:

1. Ders: Dersin genel tanitımı

2. Ders: Döşeme kaplamaları

3. Ders: İç duvar kaplamaları

4. Ders: İç bölme duvarları ve tavan kaplamalar1

5. Ders: İç kapılar

6. Ders: İç kapılar

7. Ara sinav

8. Ders: Dış duvar kaplamaları

9. Ders: Dış kapılar 
10. Ders: Pencereler

11. Ders: Pencereler

12. Ders: Karma Dış Doğramalar

13. Ders: Çatı Kaplamaları

14. Ders: Giydirme Cepheler

Ders programı kapsamında gerçekleştirilen teorik anlatımlar ve uygulama çalışmaları sonucunda elde edilmesi hedeflenen Dersin Öğrenme Kazanımları ise şunlardır:

- Öğrenci mimari detay tasarımında sorunları anlayabilir ve alternatif çözümler üretebilir.

- Öğrenci mimari detay tasarımında malzeme ve bileşen seçimini ve değerlendirilmesini, tasarım parametrelerine uygun biçimde yapabilir

- Öğrenci mimari detayları eleman, mekân ve bina bütünü ölçeğinde bütünleştirebilir.

- Öğrenci mimari detay sorunlarına yapım aşamasında müdahale edebilir ve çözüm geliştirebilir.

- Öğrenci mimari detay uygulamalarını yapım yerinde yönetebilecek bilgiye sahip olur.

- Öğrenci mimari detay çizimlerini içeren dokümanları anlayabilir.

Mimari detaylandırma konularında kazanılan bilgi birikiminin, detay çözümleme becerisine evrilebilmesi için, bu bilgiler kapsamında çizime dayalı uygulama çalışmalarının yapılması ve çalışma sonuçlarının değerlendirilerek, geri bildirim amacıyla öğrenciyle paylaşı1ması ve tartışılması önemlidir. Bu nedenle öğrenciler, her ders konusuyla ilgili hazırlanan uygulama çalışması sorularını uygulama atölyesinde öğretim elemanlar1nın denetiminde çözümleyerek çizimlerini yapar. Uygulama dersinin sonunda bu çizim paftaları öğretim elemanlarına teslim edilir. Gerçekleştirilen uygulama çalışmaları öğretim elemanları tarafından değerlendirilerek tashih edilir ve çalışmalarındaki sorunları görmesi ve düzeltmesi için öğrencilere geri verilir.

$\mathrm{Bu}$ çalışmada, öğrencilerin gerçekleştirdiği uygulama çalışmaları, ders programında hedeflenen Dersin Öğrenme Kazanımları kapsamında, aşağıdaki 10 temel kriter göz önünde bulundurularak değerlendirilmiştir (Allen, 1992; Wakita ve Linde, 1999):

1. Uygulanabilirlik (Uygulama Hatası)

2. Strüktürel Performans (Strüktürel Hata)

3. Yalıtım Performansı (Yalıtım Hatası)

4. Estetik Performans (Estetik Hata)

5. Maliyet Performansı (Maliyet Hatasi)

6. Tamamlanan Detay Sayısı (Çizilmeyen Detay)

7. Detaylardaki Çizgi Eksikleri (Çizgi Eksikliği)

8. Detaylardaki Ölçü, Bilgi Eksikleri (Ölçü, Bilgi Eksikliği)

9. Çizgi Kalitesi (Çizgi Kalitesizliği)

10. Pafta Düzeni (Pafta Düzensizliǧi)

Uygulama çalışmalarını değerlendirme sürecinde yukarıda belirtilen kriterleri içeren bir tablo düzenlenmiştir. Bu tabloda, her uygulama çalışması için kriterler kapsaminda yapılabilecek hatalar, kriterlerin alt değerlendirme kriterleri olarak belirlenmiştir. Öğrencilerin bu hatalardan birini yapması durumunda o alt kriter satırına bir işaret konulmuştur. Böylece bir alt kritere göre kaç öğrencinin hata yaptığı, bu alt kriter satırındaki işaretlerin toplanması ile belirlenebilmiştir. Her uygulama çalışması 100 tam puan üzerinden notlandırılmıştır. Uygulama çalışmalarındaki farklı detayların önem dereceleri birbirinden farklı olabildiği için, önce bir uygulama çalışmasındaki detayların kendi aralarında göreli önem ağırlıkları belirlenmiş ve bu ağırlıklara göre her detay ayrı ayrı puanlanmıştır. Bir uygulama çalıșmasındaki sınıf genelinin başarı düzeyini belirlemek amaciyla, öğrencilerin aldığı puanlar 100-90, 89-70, 79-60, 69-50, 49-40, 39-30, 29-20, 19-10, 09-00 not gruplarını içeren bir tabloyla açıklanmıştır.

\section{Uygulama Çalışmaları}

Uygulama çalışmaları, teorik derslerde anlatılan bilgilerin pekiştirilmesi ve öğrencinin detaylandırma bilgi ve becerisini geliştirmesi amacıyla yapılır. Söz konusu çalışmaların sonuçları ders programında hedeflenen öğrenme kazanımları açısından değerlendirilerek, ders programının ve ders işleyiş yönteminin olumlu ve olumsuz tarafları, sorunları ve yetersiz- 
Şekil: I

Birinci Uygulama Çalışması.
Tablo:

Birinci Uygulama Çalışmasının değerlendirilmesinde kullanilan kriterler ve bu kriterler kapsamında çizimlerde karşılaşılan hatalar.

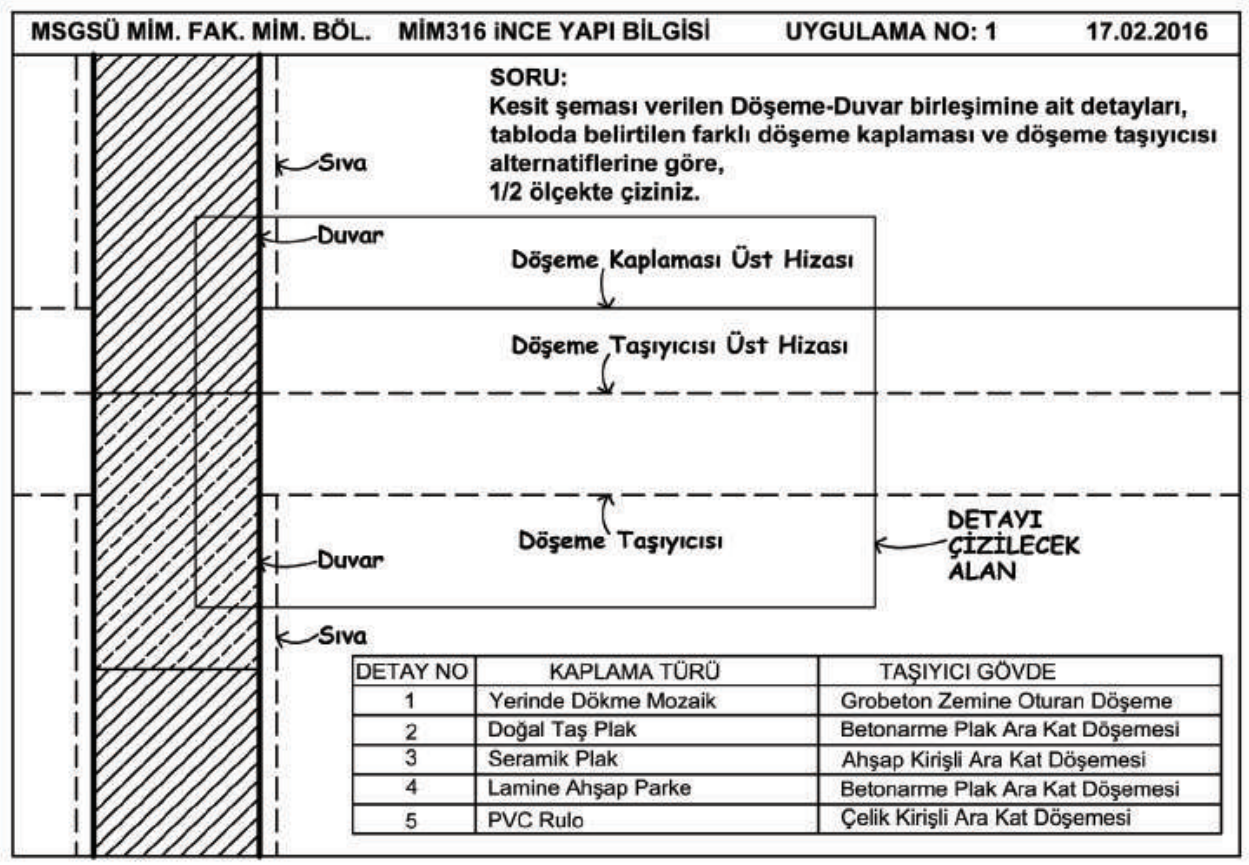

KRITERLER

\section{KARŞILAŞILAN HATALAR}

*PVC süpürgeliğin duvara tespitinin hatalı yapılması

*Kagir süpürgeliğin arkasına harç yerine sıva devam ettirilerek tespit malzemesi olarak gösterilmesi

* Montaj ve tespit hataları

*Ahşap/çelik döşeme kirişlerinin hatalı çizilmesi

*Trapez levha profilinin ve kalınlığının hatalı çizilmesi

Strüktürel Hata *Kaplama tespitini sağlayan harç kalınlığının hatalı seçilmesi

* Lamine ahşap parke altına şilte yerleştirilmemesi

$\begin{array}{ll}\text { Yalıtım Hatası } & \text { *Döşeme sisteminde yalıtım yapılmaması } \\ & \text { *Döşemedeki yalıtımın duvara doğru döndürülmemesi }\end{array}$

*Süpürgelik biçim ve boyutlarının estetik olmaması

*Süpürgeliğin tespitinde kullanılan harcın sıva kalınlığı kadar olması, süpürgelik üst yüzeyinin kalın görünmesi ve toz tutması

*Döşemedeki derz aralıklarının çok dar/geniş seçilmesi

Estetik Hata *Seramiksüpürgelik arkasındaki tespit harcının gizlenmesi için üst bitiminde PVC veya metal profil kullanılmaması

*Yerinde dökme mozaik döşemede süpürgelik ve döşeme

kaplaması arasına ayırıcı derz profili konulmaması

*Aynı yüzdeki sıva ve süpürgelik arasında fuga yapılmaması

$\begin{array}{ll}\text { Maliyet Hatası } & { }^{*} \text { Döşeme kaplamasının gerekenden kalın seçilmesi } \\ & * \text { Altık/tespit malzemelerinin gerekenden kalın seçilmesi }\end{array}$

*istenen detaylardan en az birinin veya daha fazlasının tam olarak

Çizilmeyen Detay

\begin{tabular}{ll}
\hline Çizgi Eksikliği & *Detaylarda bazı bölümlerin ve çizgilerin çizilmemiş olması \\
\hline \multirow{2}{*}{ Ölçü, Bilgi Eksikliği } & $\begin{array}{l}\text { *Ölçü ve bilgilerin her detayda belirtilmemiş veya eksik belirtilmiş } \\
\text { olması }\end{array}$ \\
\hline \multirow{2}{*}{ Çizgi Kalitesizliği } & $\begin{array}{l}\text { *Plan, kesit ve görünüş çizimlerindeki çizgi türlerinin ve } \\
\text { kalınlıklarının çizim standartlarına uygun olmaması }\end{array}$ \\
\hline \multirow{2}{*}{ Pafta Düzensizliği } & $\begin{array}{l}\text { *Öğrenci ismi, detay ismi, uygulama numarası vb. ifadelerin hiç } \\
\text { belirtilmemiş veya karmaşık olması }\end{array}$ \\
\hline
\end{tabular}


likleri saptanabilir. Bu nedenle 2015-2016 Bahar Dönemi süresince gerçekleştirilen uygulama çalışmaları, yukarıda belirtilen kriterlere göre değerlendirilmiş ve öğrencilerin her çalışmada gösterdikleri performans durumları tablolarla açıklanmıştır. Dönemin ilk ve son haftalarında uygulama çalışması yapılmamış, 7 . haftada ise bir ara sınav yapılmıştır. Dönem içinde toplam 11 adet uygulama çalışması gerçekleştirilmiş, bu çalışmaların 10 adeti değerlendirilip puanlanmıştır. Gerçekleştirilen her uygulama çalışmasının işleyişi ve değerlendirme sonuçları aşağıdaki başlıklar altında açıklanmıştır.

\subsection{Birinci Uygulama Çalışması}

Uygulama yapılmayan birinci derste İnce Yapı Bilgisi dersinin programı, işleyişi ve kurallarının genel tanıtımı yapılmış, dersle ilgili temel kavramlar, mimari detaylandırmada kullanılan malzeme, bileşen ve elemanlar açıklanmıştır. 17.02.2016 tarihinde gerçekleştirilmiş olan ikinci dersin teorik bölümünde döşeme sistemi, döşeme kaplamaları, döşeme kaplamalarının uygulanma olanakları ve türleri anlatılmış, döşeme sisteminin detaylandırılma ilkeleri açıklanmıştır. Dersin uygulamalı bölümünde ise Şekil 1'de gösterilen Birinci Uygulama Çalışması sorusundaki 5 adet nokta detayının çözümlenmesi ve çizilmesi istenmiştir. Döşeme sisteminin yanı sıra, döşeme ile duvar birleşim detaylarını da içeren bu soruda, farklı döşeme taşıyıcıları üzerine uygulanan farklı döşeme kaplamalarının kullanılması istenmiştir.

Birinci Uygulama Çalışmasına katılan toplam 69 öğrencinin çizimleri, Tablo 1'de açıllanan kriterler kapsamında ve çizimlerde karşılaşılan hatalar doğrultusunda değerlendirilmiş, ortaya çıkan sonuçlar Şekil 2'de belirtilmiştir. Birinci Uygulama Çalışmasında sınıfın genel başarı düzeyi Şekil 3'de gösterilmiştir.

\subsection{Ikinci Uygulama Çalışması}

24.02.2016 tarihinde gerçekleştirilmiş olan

\section{9}
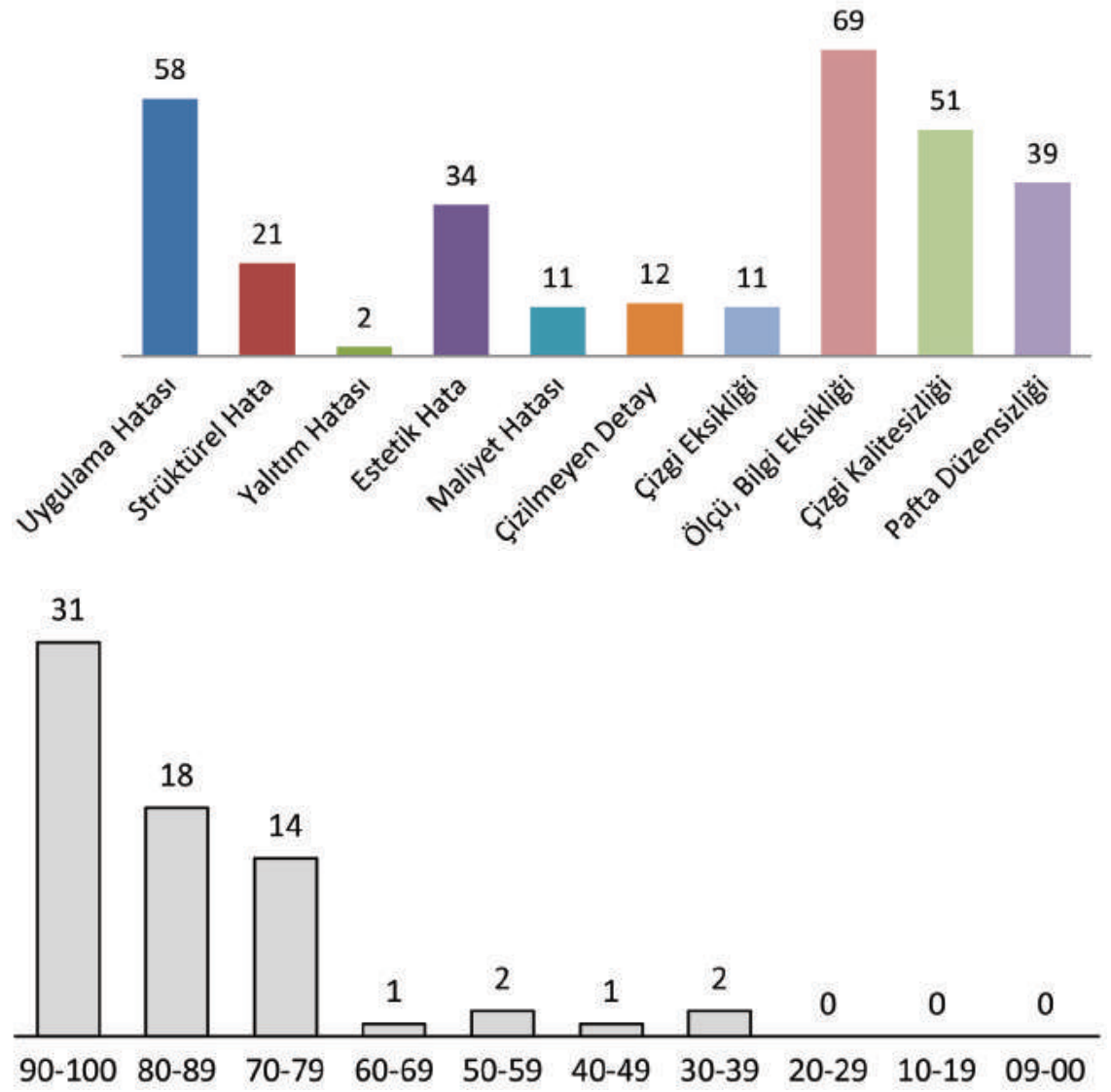

Şekil: 2

Birinci Uygulama Çalışmasında belirlenen kriterlere göre hata yapan ögrencilerin sayısı.
Şekil: 3

Birinci Uygulama Çalısmasında aldıkları puanlara göre öğrencilerin sayısı. 
Şekil: 4

ikinci Uygulama Çalışması.

Şekil: 5

ikinci Uygulama çalışmasında

belirlenen kriterlere göre hata yapan

ögrencilerin sayısı.

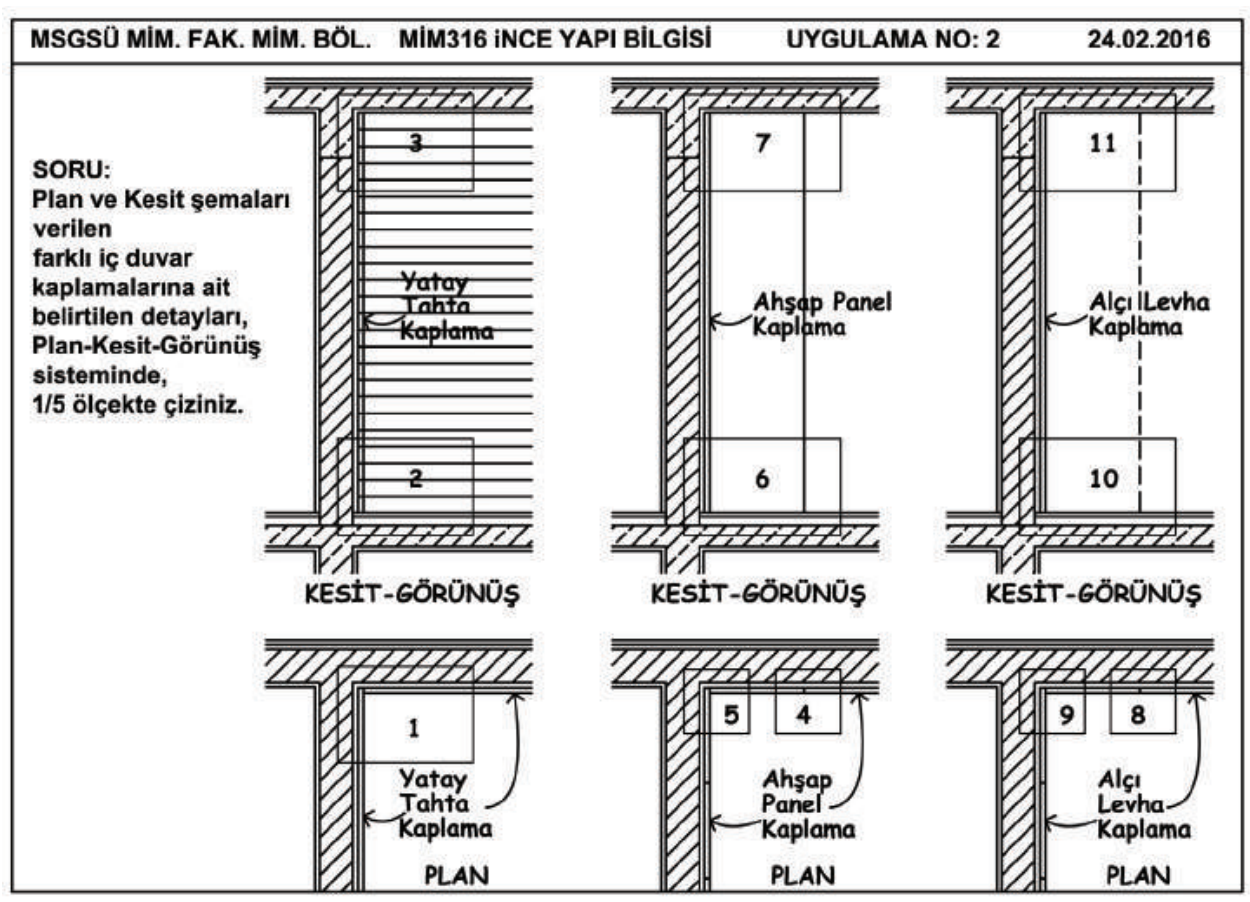

üçüncü dersin teorik bölümünde iç duvar sistemi, iç duvar kaplamalarının işlevleri, özellikleri, uygulanma olanakları ve çeşitli türleri anlatılmış, detaylandırılma ilkeleri açıklanmıştır. Dersin uygulamalı bölümünde ise, Şekil 4'te gösterilen İkinci Uygulama Çalışması sorusundaki 3 farklı iç duvar kaplamasına (yatay tahta, ahşap panel ve alçı levha duvar kaplamalarına) ait detayların plan-kesit-görünüş sisteminde çözümlenmesi ve çizilmesi istenmiştir. Bu soruda plan çizimleri kaplama birleşimlerini ve köşe dönüşünü, kesit çizimleri ise kaplamaların döşeme ve tavan ile birleşimlerini içermektedir.
İkinci Uygulama Çalışmasına katılan toplam 70 öğrencinin çizimleri, Tablo 2'de açıklanan kriterler kapsamında ve çizimlerde karşılaşılan hatalar doğrultusunda değerlendirilmiş, ortaya çıkan sonuçlar Şekil 5'te belirtilmiştir. İkinci Uygulama Çalışmasında sınıfın genel başarı düzeyi Şekil 6'da gösterilmiştir.

\section{3. Üçüncü Uygulama Çalışması}

02.03.2016 tarihinde gerçekleştirilmiş olan dördüncü dersin teorik bölümünde tavan kaplamaları, tavan kaplamalarının uygulanma olanakları ve türleri, tavan sistemlerinin detaylandırılma ilkeleri, bölme duvar türleri ve uygulamaları ve

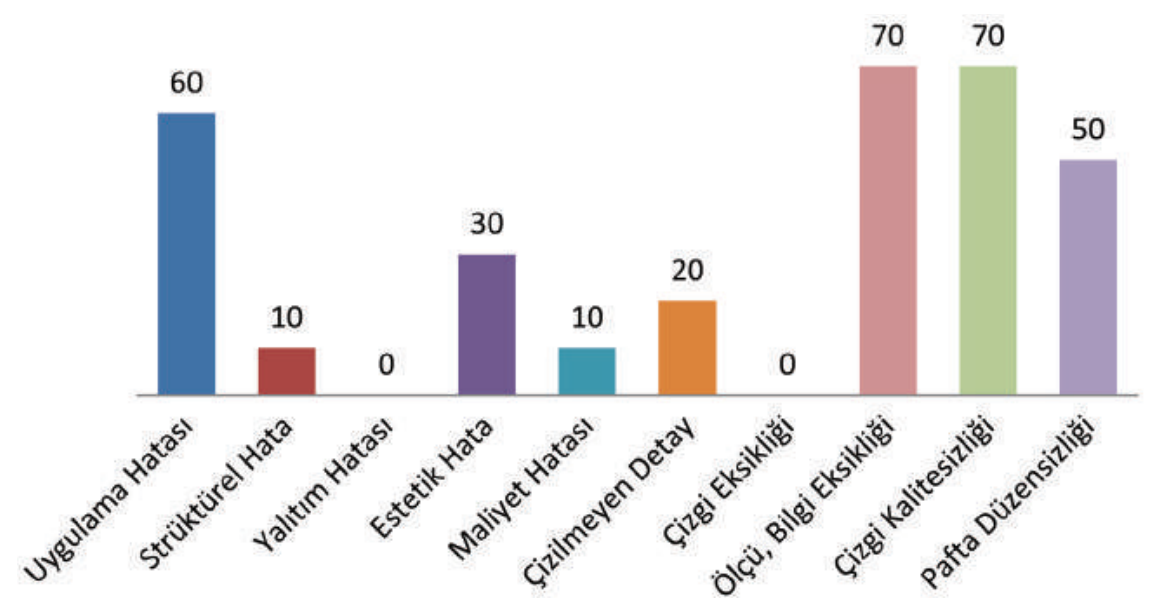




\begin{tabular}{|c|c|}
\hline KRITERLER & KARŞILAŞILAN HATALAR \\
\hline Uygulama Hatası & $\begin{array}{l}\text { *Ahşap duvar kaplamaları ile tavan veya bitiş pervazı arasında } \\
\text { montaj için yeterli mesafe bırakılmaması } \\
\text { *Ahşap duvar kaplamalarının köşe dönüşlerde uygun montaj } \\
\text { sırasının veya lata düzeninin oluşturulmaması } \\
\text { *Askı elemanlarının ters takııması } \\
\text { *Montaj ve tespit hataları }\end{array}$ \\
\hline Strüktürel Hata & $\begin{array}{l}\text { *Kaplama taşıyıcı ızgara (lata) boyutlarının hatalı seçilmesi } \\
\text { *Duvar kaplama kalınlıklarının hatalı seçilmesi } \\
\text { *Ahşap duvar kaplamaları arasında genleşme derzi bırakılmaması } \\
\text { *Askı elemanlarının yeterli boyutlarda seçilmemesi }\end{array}$ \\
\hline Yalıtım Hatası & - \\
\hline Estetik Hata & $\begin{array}{l}\text { *Süpürgelik biçim ve boyutlarının estetik olmaması } \\
\text { *Süpürgeliğin tespit şeklinin estetik olmaması } \\
\text { *Döşemedeki derz aralıklarının çok dar/geniş seçilmesi } \\
\text { *Ahşap duvar kaplama bileşenleri arasındaki fugaların çok dar } \\
\text { seçilmesi veya hiç yapıımaması } \\
\text { *Süpürgeliğin üst yüzeyinin kalın görünmesi ve toz tutması }\end{array}$ \\
\hline Maliyet Hatası & $\begin{array}{l}\text { *Döşeme kaplamasının gerekenden kalın seçilmesi } \\
\text { *Altlık/tespit malzemelerinin gerekenden kalın seçilmesi }\end{array}$ \\
\hline Çizilmeyen Detay & $\begin{array}{l}\text { *istenen detaylardan en az birinin veya daha fazlasının tam olarak } \\
\text { çizilip bitirilmemesi }\end{array}$ \\
\hline Çizgi Eksikliği & *Detaylarda bazı bölümlerin ve çizgilerin çizilmemiş olması \\
\hline Ölçü, Bilgi Eksikliği & $\begin{array}{l}\text { *Ölçü ve bilgilerin her detayda belirtilmemiş veya eksik belirtilmiş } \\
\text { olması }\end{array}$ \\
\hline Çizgi Kalitesizliği & $\begin{array}{l}\text { *Plan, kesit ve görünüş çizimlerindeki çizgi türlerinin ve } \\
\text { kalınlıklarının çizim standartlarına uygun olmaması }\end{array}$ \\
\hline Pafta Düzensizliği & $\begin{array}{l}\text { *Öğrenci ismi, detay ismi, uygulama numarası vb. ifadelerin hiç } \\
\text { belirtilmemiş veya karmaşık olması }\end{array}$ \\
\hline
\end{tabular}

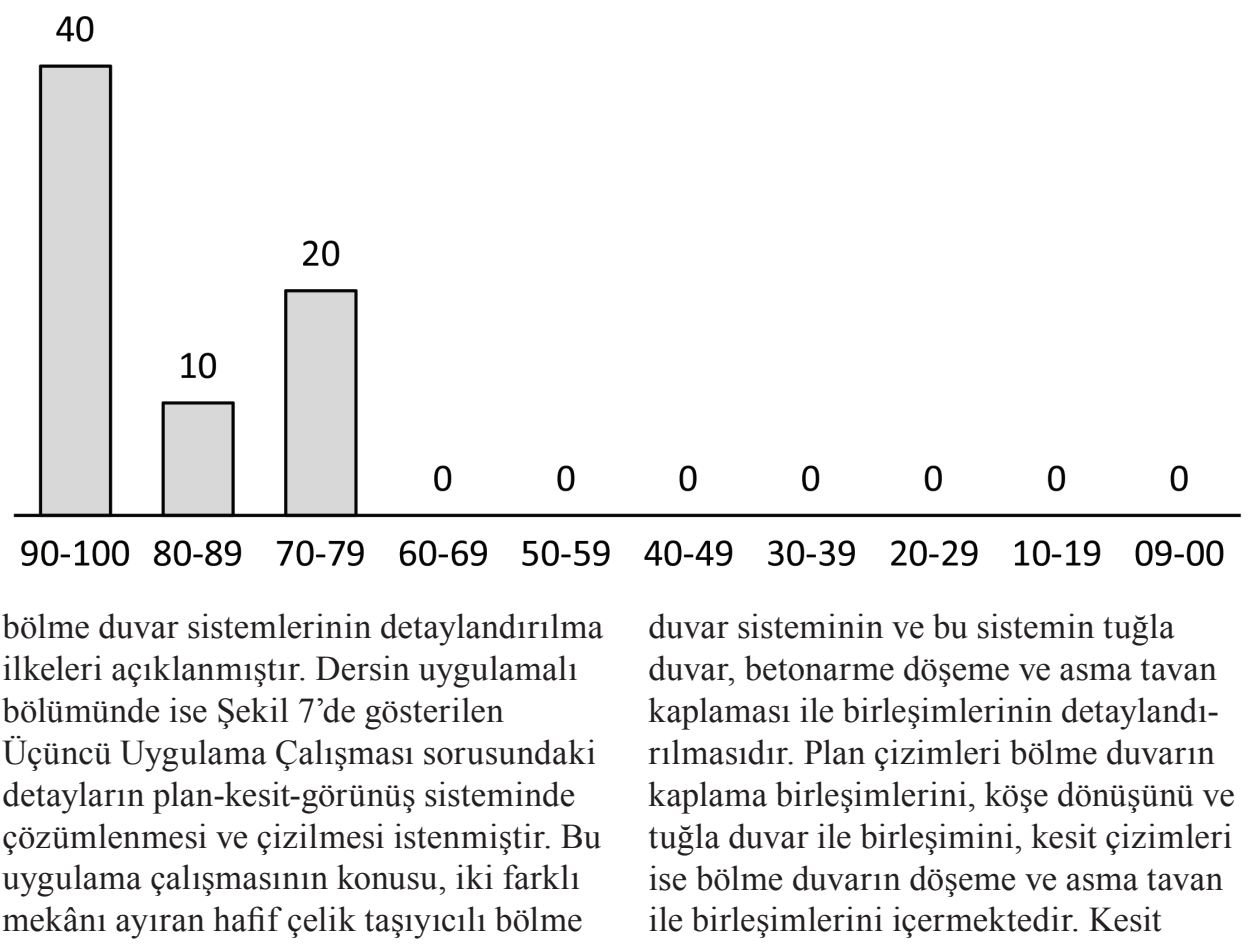

Tablo: 2

ikinci Uygulama Çalışmasının değerlendirilmesinde kullanilan kriterler ve bu kriterler kapsaminda çizimlerde karşılaşılan hatalar.
Şekil: 6

Ikinci Uygulama Çalışmasında aldıkları puanlara göre öğrencilerin sayısı. 
Şekil: 7

Ü̧üncü Uygulama f̧alışması.

Şekil: 8

Ü̧̧üncü Uygulama Çalışmasında belirlenen kriterlere göre hata yapan ögrencilerin sayısı.

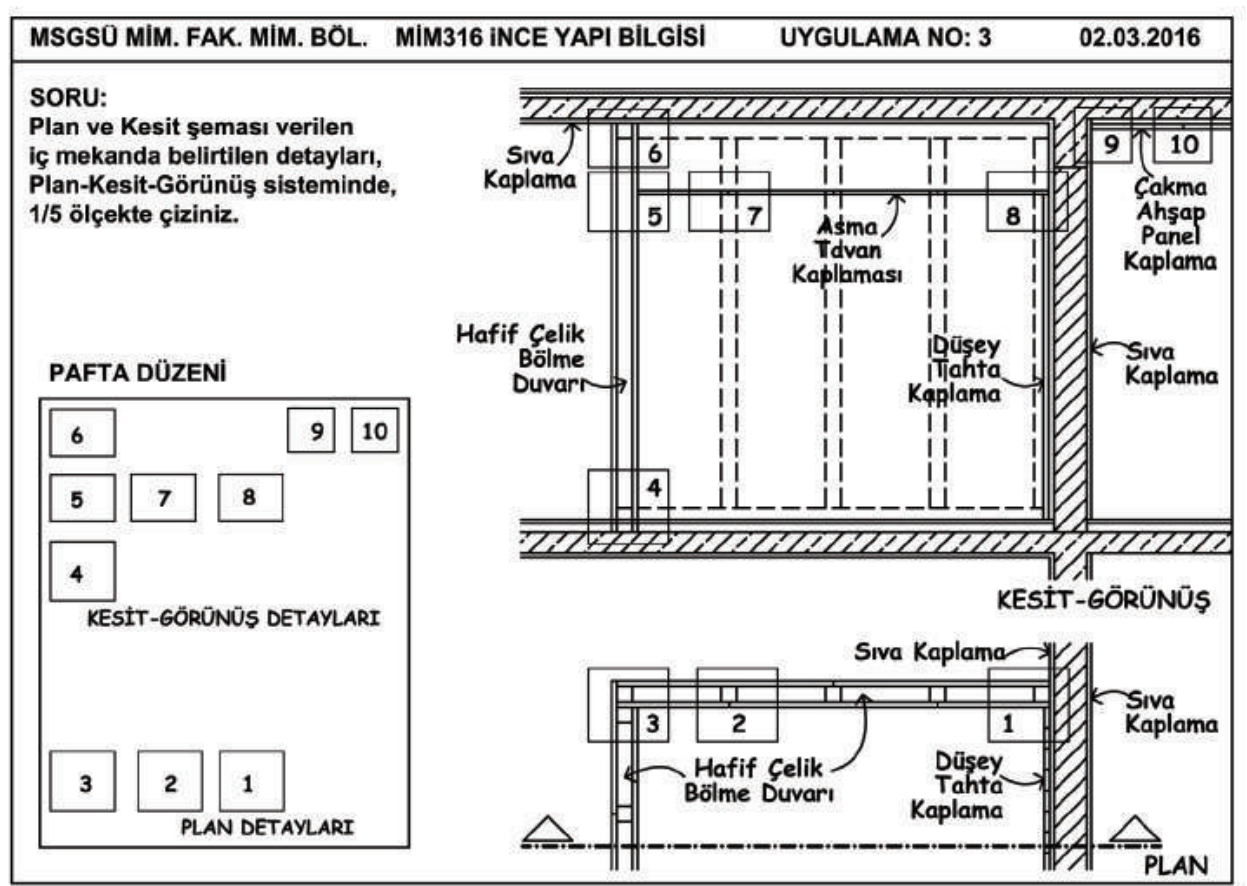

çizimleri ayrıca asma tavan kaplama birleşimlerini ve asma tavan kaplaması ile tuğla duvar birleşimini de içermektedir. Hafif çelik taşıyıcılı bölme duvarın betonarme tavan ve döşeme ile birleşiminin çiziminde döşeme kaplamalarının süpürgelik ile ilişkilerinin, alt katmanların ve tespit yöntemlerinin belirtilmesi gerektiği vurgulanmıştır. Asma tavan kaplaması, mekânın bir yanında bölücü duvar, diğer yanında ise tuğla duvar ile ilişkilendirildiği için farklı detay çözümleri ortaya çıkmıştır. Tuğla duvarın bir yüzü düşey tahta kaplama diğer yüzü ise sıva kaplamalıdır.

Üçüncü Uygulama Çalışmasına katılan toplam 62 öğrencinin çizimleri, Tablo 3'de açıklanan kriterler kapsamında ve çizimlerde karşılaşılan hatalar doğrultusunda değerlendirilmiş, ortaya çıkan sonuçlar Şekil 8'de belirtilmiştir. Üçüncü Uygulama Çalışmasında sınıfın genel başarı düzeyi Şekil 9'da gösterilmiştir.

\subsection{Dördüncü Uygulama Çalışması}

09.03.2016 tarihinde gerçekleştirilmiş olan

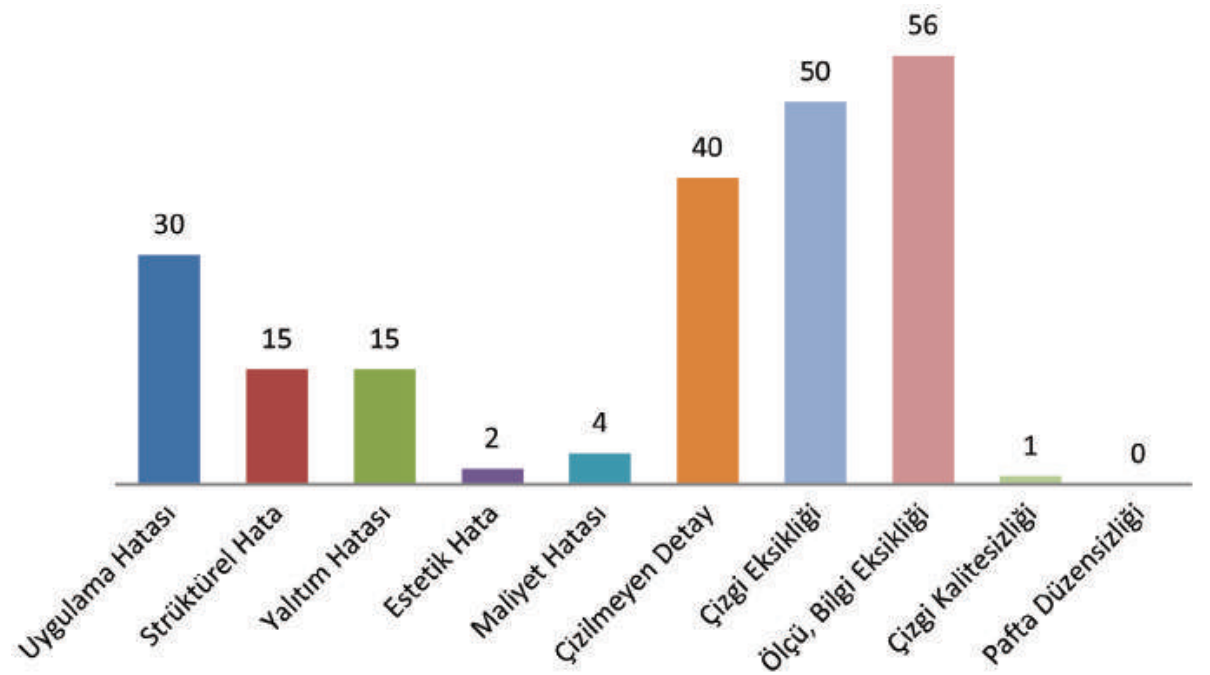


KRITERLER

KARŞILAŞILAN HATALAR

*Ahşap duvar kaplamaları ile tavan veya bitiş pervazı arasında montaj için yeterli mesafe bırakılmaması

*Hafif çelik bölme duvarı taşıyıcılarının doğru detaylandırımamış

Uygulama Hatası olması

*Asma tavan kaplaması ile duvar kaplamasının hatalı birleştirilmesi

* Duvar ve tavan kaplamalarının montajının yapılamaması

*Montaj ve tespit hataları

*Tahta duvar kaplamalarını taşıyan lata boyutlarının hatalı seçilmesi

*Tahta kaplama kalınlıklarının hatalı seçilmesi

*Tahta kaplamalar arasında genleşme derzi bırakılmaması

*Asma tavan askı elemanlarının taşıyıcılık işlevini yapamaması

*Çakma tahta tavan kaplamasını taşıyan lata boyutlarının hatalı

Strüktürel Hata seçilmesi

*Hafif çelik bölme duvarında taşıyıcı profillerin hatalı

detaylandırılması

*Alçı levha kalınlığının hatalı seçilmesi

*Hafif çelik bölme duvarının tavan ve döşemeye tespitinde tavan ve taban U profillerinin kullanılmaması

\begin{tabular}{|c|c|}
\hline Yalıtım Hatası & *Hafif çelik bölme duvarı içinde yalıtım malzemesi kullanılmaması \\
\hline \multirow{6}{*}{ Estetik Hata } & *Süpürgelik boyutlarının ve biçimlerinin estetik olmaması \\
\hline & *Süpürgeliğin tespit şeklinin estetik olmaması \\
\hline & *Döşemedeki derz aralıklarının çok dar/geniş seçilmesi \\
\hline & *Ahşap duvar kaplama bileşenleri arasındaki fugaların çok dar \\
\hline & seçilmesi veya hiç yapılmaması \\
\hline & *Süpürgeliğin/pervazın üst yüzeyinin kalın görünmesi ve toz tutmas \\
\hline \multirow{3}{*}{ Maliyet Hatası } & *Döşeme kaplamasının gerekenden kalın seçilmesi \\
\hline & *Altlık/tespit malzemelerinin gerekenden kalın seçilmesi \\
\hline & *Tavan kaplamasının gerekenden kalın seçilmesi \\
\hline Çizilmeyen Detay & $\begin{array}{l}\text { *istenen detaylardan en az birinin veya daha fazlasının tam olarak } \\
\text { çizilip bitirilmemesi }\end{array}$ \\
\hline Çizgi Eksikliği & *Detaylarda bazı bölümlerin ve çizgilerin çizilmemiş olması \\
\hline Ölçü, Bilgi Eksikliği & $\begin{array}{l}\text { *Ölçü ve bilgilerin her detayda belirtilmemiş veya eksik belirtilmiş } \\
\text { olması }\end{array}$ \\
\hline Çizgi Kalitesizliği & $\begin{array}{l}\text { *Plan, kesit ve görünüş çizimlerindeki çizgi türlerinin ve } \\
\text { kalınlıklarının çizim standartlarına uygun olmaması }\end{array}$ \\
\hline Pafta Düzensizliği & $\begin{array}{l}\text { *Öğrenci ismi, detay ismi, uygulama numarası vb. ifadelerin hiç } \\
\text { belirtilmemiş veya karmaşı olması }\end{array}$ \\
\hline
\end{tabular}

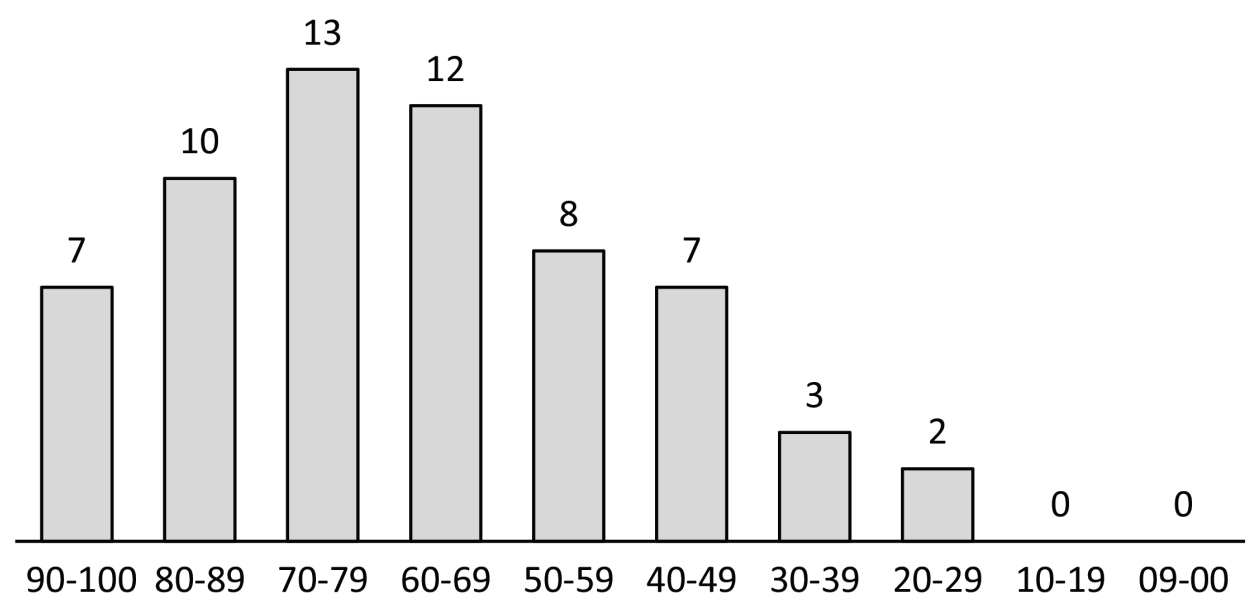

Tablo: 3

Ü̧̧йncü Uygulama Çalışmasının değerlendirilmesinde kullanılan kriterler ve bu kriterler kapsaminda çizimlerde karşılaşılan hatalar.
Şekil: 9

Ü̧üncü Uygulama Çalışmasında aldıkları puanlara göre öğrencilerin sayısı. 
Şekil: 10

Dördüncü Uygulama Çalışması.
Şekil: II

Dördüncü Uygulama Çalışmasında belirlenen kriterlere göre hata yapan ögrencilerin sayısı.

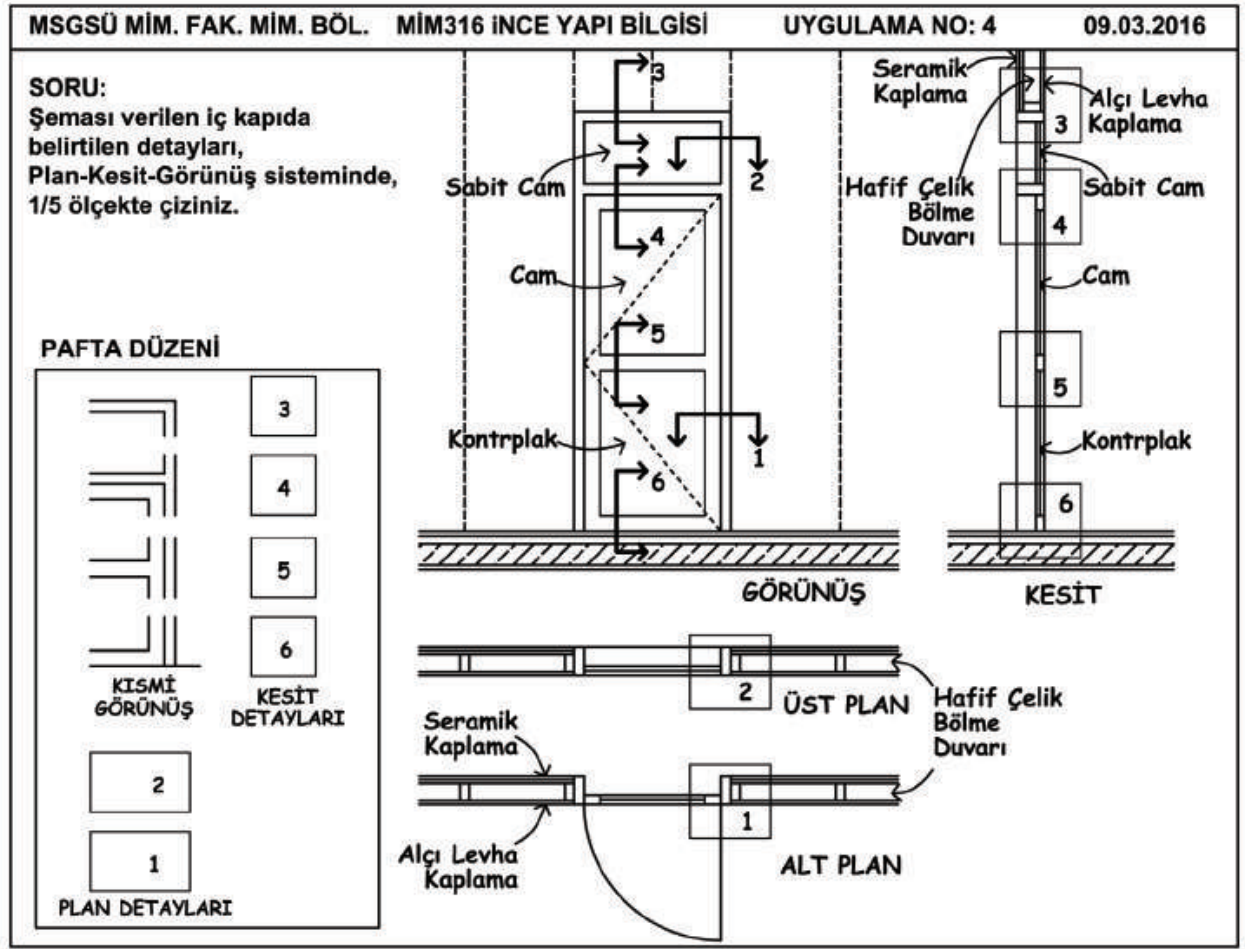

beşinci dersin teorik bölümünde iç kapı sistemi, iç kapılarda duvar-kasa, kasa-cam, kasa-kanat ve kanat-döşeme birleşim ilkeleri, ahşap çerçeveli tablalı iç kapı kanadı türleri, çerçeveli tablalı kanatlı ahşap iç kapı sisteminin detaylandırılma ilkeleri, tek kanatlı ve üstü sabit camlı ahşap iç kapı doğrama sisteminin detaylandırılma ilkeleri açıklanmıştır. Dersin uygulamalı bölümünde ise Şekil 10'da gösterilen Dördüncü Uygulama Çalışması sorusundaki detayların plan-kesit-görünüş sisteminde çözümlenmesi ve çizilmesi istenmiştir. Bu uygulama çalışmasının konusu, hafif çelik taşıyıcılı bölme duvarı

içinde düzenlenen, ahşap çerçeveli tablalı iç kapı kanadı ve üstünde sabit camı olan ahşap iç kapı sisteminin detaylandırılmasıdır. Bölme duvarının bir yüzü seramik plak diğer yüzü ise alçı levha ile kaplıdır. Ahşap iç kapı kanadının tabla malzemeleri ise cam ve kontrplaktır.

Dördüncü Uygulama Çalışmasına katılan toplam 59 öğrencinin çizimleri, Tablo 4'de açıklanan kriterler kapsamında ve çizimlerde karşılaşılan hatalar doğrultusunda değerlendirilmiş, ortaya çıkan sonuçlar Şekil 11'de belirtilmiştir. Dördüncü Uygulama Çalışmasında sınıfın genel başarı düzeyi Şekil 12'de gösterilmiştir.

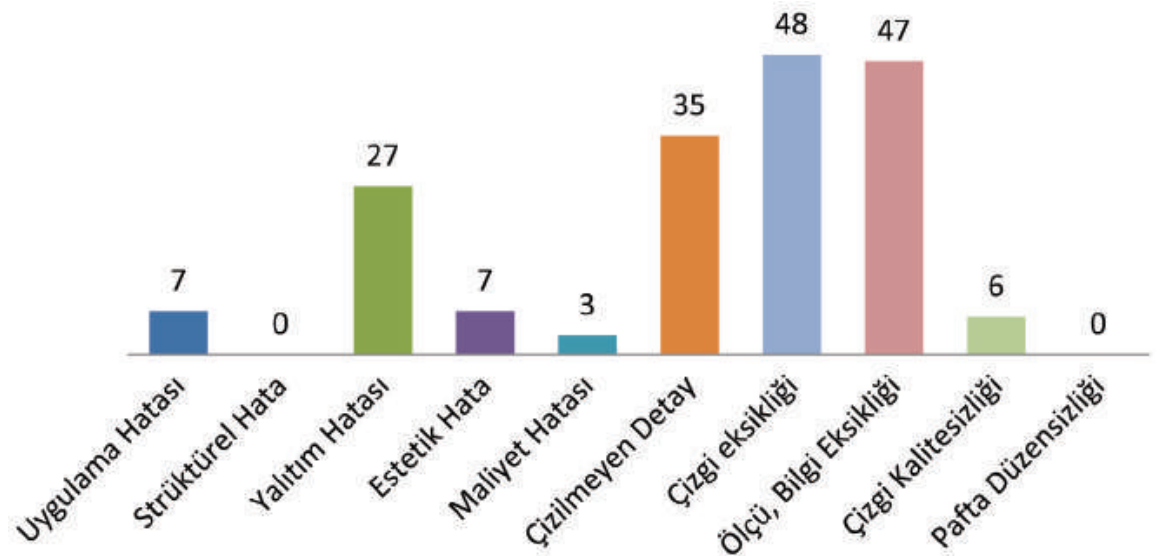




\begin{tabular}{|c|c|}
\hline KRITERLER & KARŞILAŞILAN HATALAR \\
\hline \multirow{4}{*}{ Uygulama Hatası } & *Kesit detayında sabit cam ile açılan kanat arasında kasa yapılmaması \\
\hline & *Kanadın her iki yan kenarına menteşe takılması \\
\hline & $\begin{array}{l}\text { *Tabla malzemesinin tespitini sağlayan çıta boyutlarının hatalı } \\
\text { seçilmesi }\end{array}$ \\
\hline & *Montaj ve tespit hataları \\
\hline \multirow{2}{*}{ Strüktürel Hata } & *Hafif çelik bölme duvarında taşıyıcı profillerin hatalı \\
\hline & $\begin{array}{l}\text { detaylandırılması } \\
\text { *Alçı levha kalınlığının hatalı seçilmesi }\end{array}$ \\
\hline \multirow[b]{2}{*}{ Yalıtım Hatası } & *Kasa-duvar birleşiminde yalıtım yapılmaması \\
\hline & $\begin{array}{l}\text { *Hafif çelik bölme duvarı içinde yalıtım malzemesi kullanılmaması } \\
\text { *Kasa-kanat birleşiminde bini yapılmaması }\end{array}$ \\
\hline Estetik Hata & $\begin{array}{l}\text { *Kasa ve kanat kesitlerinin gerekenden büyük boyutlarda seçilmesi } \\
\text { *Tabla tespitinde kullanılan çıta boyut ve biçiminin estetik olmaması }\end{array}$ \\
\hline Maliyet Hatası & $\begin{array}{l}\text { *Kasa ve kanat kesitlerinin gerekenden büyük boyutlarda seçilmesi } \\
\text { *Tabla malzemelerinin gerekenden kalın seçilmesi } \\
\text { *Tabla tespitinde kullanılan çıta kesitlerinin gerekenden büyük } \\
\text { boyutlarda seçilmesi }\end{array}$ \\
\hline Çizilmeyen Detay & $\begin{array}{l}\text { *istenen detaylardan en az birinin veya daha fazlasının tam olarak } \\
\text { çizilip bitirilmemesi }\end{array}$ \\
\hline Çizgi Eksikliği & *Detaylarda bazı bölümlerin ve çizgilerin çizilmemiş olması \\
\hline Ölçü, Bilgi Eksikliği & $\begin{array}{l}\text { *Ölçü ve bilgilerin her detayda belirtilmemiş veya eksik belirtilmiş } \\
\text { olması }\end{array}$ \\
\hline Çizgi Kalitesizliği & $\begin{array}{l}\text { *Plan, kesit ve görünüş çizimlerindeki çizgi türlerinin ve kalınlıklarının } \\
\text { çizim standartlarına uygun olmaması }\end{array}$ \\
\hline Pafta Düzensizliği & $\begin{array}{l}\text { *Öğrenci ismi, detay ismi, uygulama numarası vb. ifadelerin hiç } \\
\text { belirtilmemiş veya karmaşık olması }\end{array}$ \\
\hline
\end{tabular}

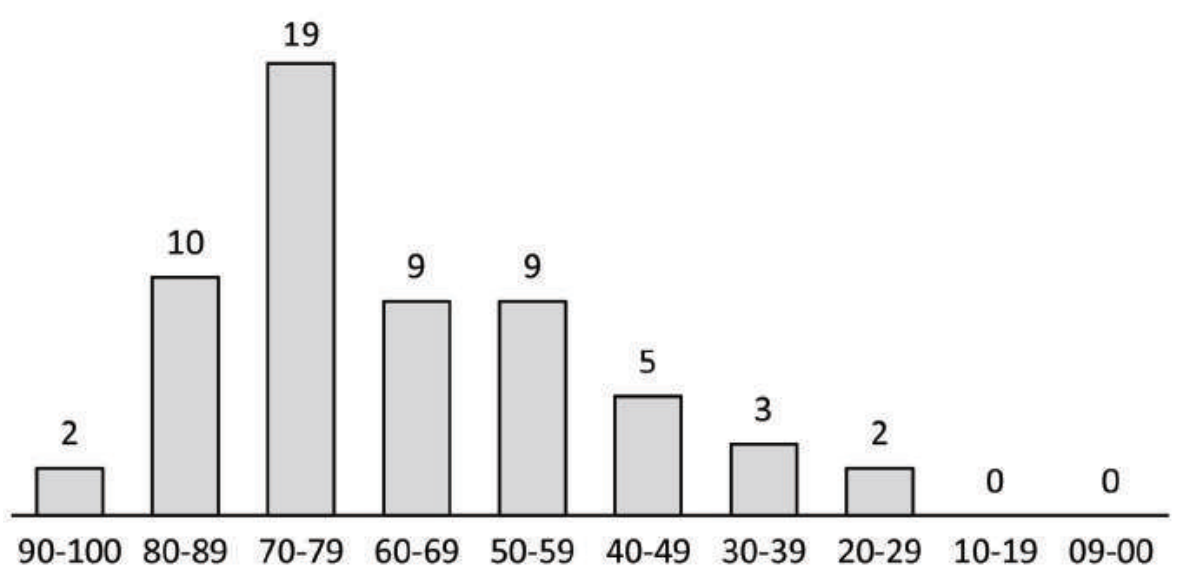

\subsection{Beşinci Uygulama Çalışması}

16.03.2016 tarihinde gerçekleştirilmiş olan altıncı dersin teorik bölümünde iç kapı sistemi, ahşap prese iç kapı kanadı türleri, ahşap prese kanatlı iç kapı sisteminin detaylandırılma ilkeleri, iki kanatlı ahşap iç kapı doğrama sisteminin detaylandırılma ilkeleri açıklanmıştır. Dersin uygulamalı bölümünde ise Şekil 13'te gösterilen Beşinci Uygulama Çalışması sorusundaki detayların plan-kesit-görünüş sisteminde çözümlenmesi ve çizilmesi istenmiştir. Bu uygulama çalışmasının konusu, tuğla duvar içerisinde düzenlenen, ahşap prese asimetrik iki kanatlı iç kapı sisteminin detaylandırılmasıdır. Asimetrik kanatlardan dar olanı kafes dolgulu ahşap prese kanat, geniş olanı ise düşey lata dolgulu ahşap prese kanattır. $9 \mathrm{~cm}$ kalınlığındaki tuğla duvarın bir yüzü alçı levha, diğer yüzü ise düşey tahta kaplamalıdır. Soruda verilen mekânın üstü asma tavan kaplamasıyla
Tablo: 4

Dördüncü Uygulama Çalışmasının değerlendirilmesinde kullanilan kriterler ve bu kriterler kapsaminda çizimlerde karşılaşılan hatalar.
Sekil: 12

Dördüncü Uygulama Çalışmasında aldıkları puanlara göre öğrencilerin sayıs.. 
Şekil: 13

Beşinci Uygulama Çalışması.
Tablo: 5

Beşinci Uygulama Çalışmasının değerlendirilmesinde kullanılan kriterler ve bu kriterler kapsaminda çizimlerde karşılaşılan hatalar.

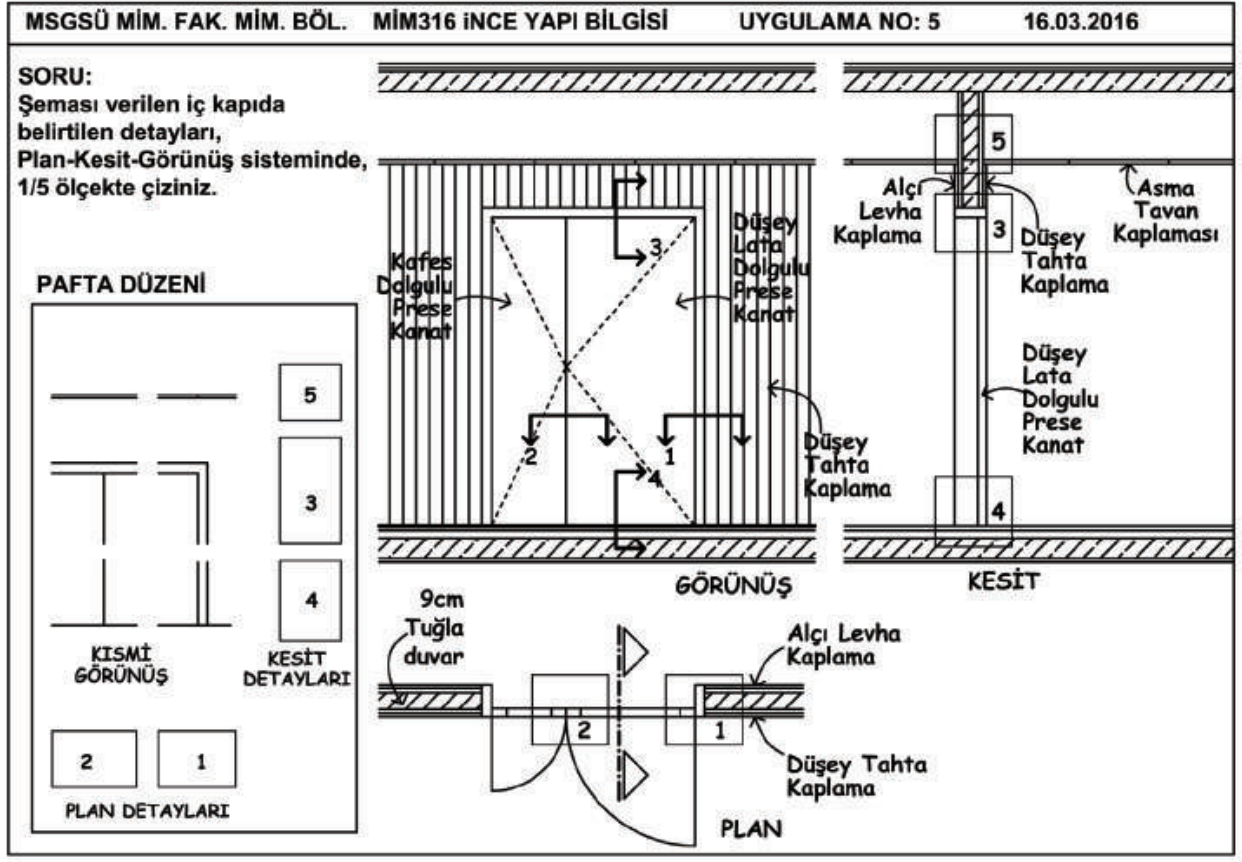

KRITERLER

\begin{tabular}{|c|c|}
\hline & *Kasanın duvara tespitinin yapılamaması \\
\hline & *Menteşelerin kanatlarda doğru yerlere yerleştirilmemesi \\
\hline \multirow[t]{3}{*}{ Uygulama Hatası } & *Duvar ve tavan kaplamalarının montajının yapılamaması \\
\hline & $\begin{array}{l}\text { *iki kanat birleşim çözümünde, önce geniş kanadın açılamaması } \\
\text { *Montaj ve tespit hataları }\end{array}$ \\
\hline & *Kasanın duvara bağlantısının yapılmaması \\
\hline \multirow[t]{2}{*}{ Strüktürel Hata } & $\begin{array}{l}\text { *Prese kanat çerçeve kesitinin hatalı boyutlarda seçilmesi } \\
\text { *Alçı levha kaplamaları taşıyan lata boyutlarının hatalı seçilmesi } \\
\text { *Alçı levha kalınlığının hatalı seçilmesi }\end{array}$ \\
\hline & *Kasa-duvar birleşiminde yalıtım yapılmaması \\
\hline Yalıtım Hatası & $\begin{array}{l}\text { *Kasa-kanat birleşiminde bini yapılmaması } \\
\text { *Prese kanat içinde Isı yalıtım malzemesi kullanılmaması }\end{array}$ \\
\hline \multirow[b]{2}{*}{ Estetik Hata } & *Kasa kesitinin gerekenden büyük boyutlarda seçilmesi \\
\hline & $\begin{array}{l}\text { *Kanat yüzeylerinde masif bölüm ile kaplamalı bölüm ilişkisinin } \\
\text { estetikolmaması } \\
\text { *Kanat yüzeyinde tabla tespiti için kullanılan çıta boyut ve biçiminin } \\
\text { estetik olmaması }\end{array}$ \\
\hline & *Kasa ve kanat kesitlerinin gerekenden büyük boyutlarda seçilmesi \\
\hline Maliyet Hatası & $\begin{array}{l}\text { *Prese kanat çerçeve kesitinin gerekenden büyük boyutlarda } \\
\text { seçilmesi }\end{array}$ \\
\hline Çizilmeyen Detay & $\begin{array}{l}\text { *istenen detaylardan en az birinin veya daha fazlasının tam olarak } \\
\text { çizilip bitirilmemesi }\end{array}$ \\
\hline Çizgi Eksikliği & *Detaylarda bazı bölümlerin ve çizgilerin çizilmemiş olması \\
\hline Ölçü, Bilgi Eksikliği & $\begin{array}{l}\text { *Ölçü ve bilgilerin her detayda belirtilmemiş veya eksik belirtilmiş } \\
\text { olması }\end{array}$ \\
\hline Çizgi Kalitesizliği & $\begin{array}{l}\text { *Plan, kesit ve görünüş çizimlerindeki çizgi türlerinin ve kalınlıklarının } \\
\text { çizim standartlarına uygun olmaması }\end{array}$ \\
\hline Pafta Düzensizliği & $\begin{array}{l}\text { *Öğrenci ismi, detay ismi, uygulama numarası vb. ifadelerin hiç } \\
\text { belirtilmemiş veya karmaşık olması }\end{array}$ \\
\hline
\end{tabular}




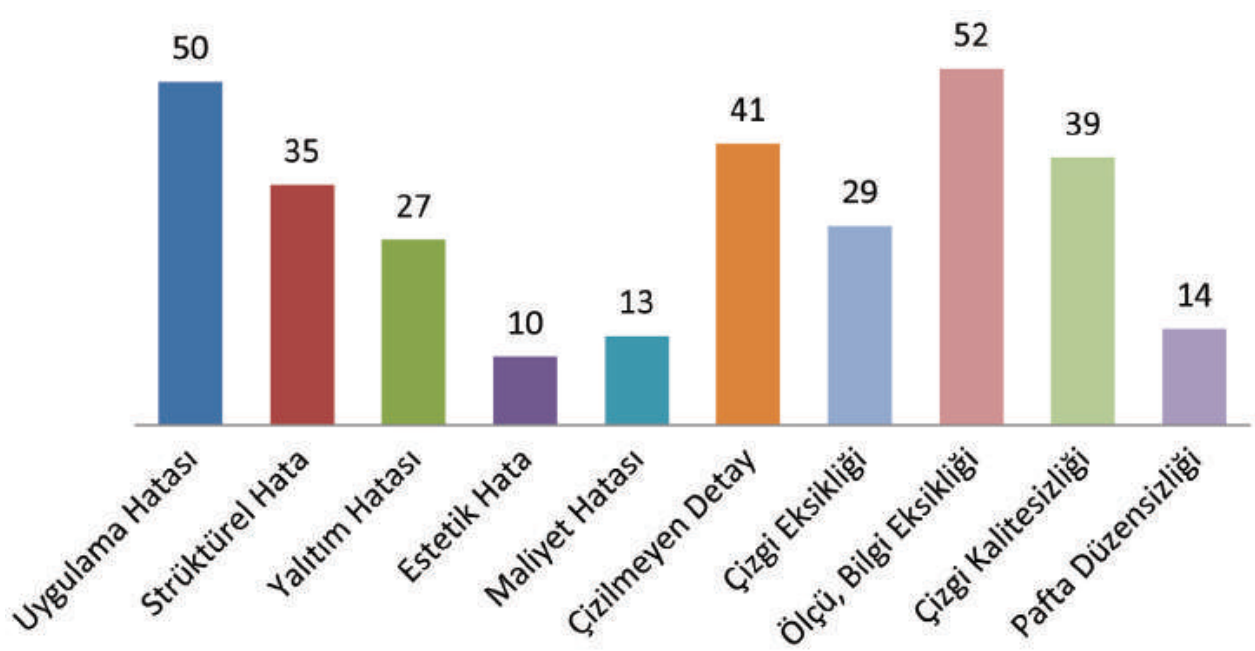

16

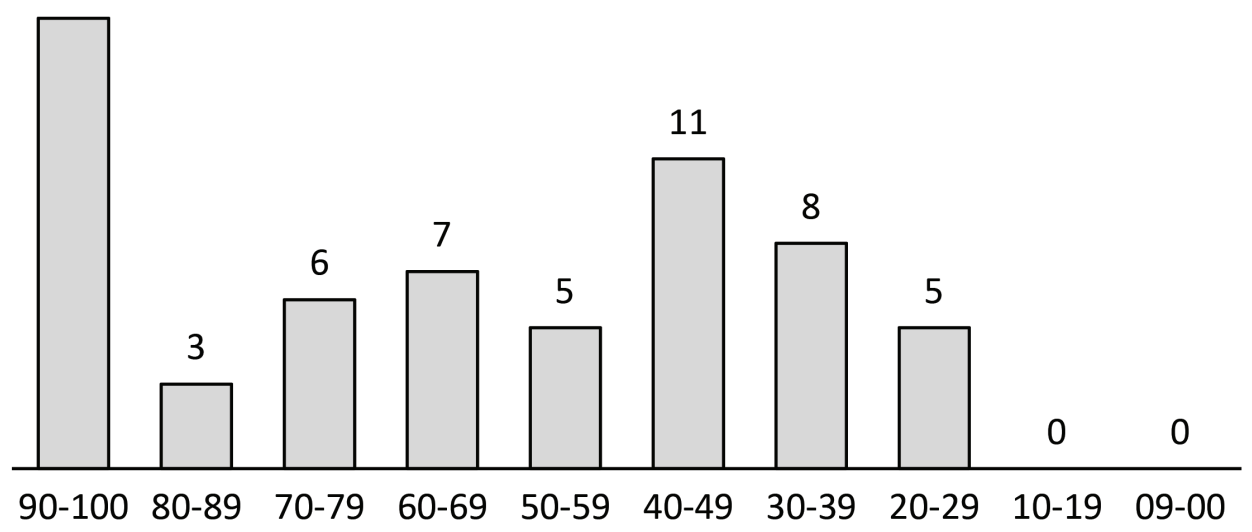

örtülüdür. Döşeme kaplaması türü ise öğrencinin seçimine bırakılmıştır.

Beşinci Uygulama Çalışmasına katılan toplam 61 öğrencinin çizimleri, Tablo 5'de açıklanan kriterler kapsamında ve çizimlerde karşılaşılan hatalar doğrultusunda değerlendirilmiş, ortaya çıkan sonuçlar Şekil 14'te belirtilmiştir. Beşinci Uygulama Çalışmasında sınıfın genel başarı düzeyi Şekil 15’te gösterilmiştir.

\subsection{Altıncı Uygulama Çalışması}

23.03.2016 tarihinde, bina iç bölme sisteminin detaylandırması konularını içeren ara sınav yapılmış, teorik ders ve uygulama yapılmamıştır. 30.03.2016 tarihinde yedinci ders gerçekleştirilmiş, bu dersin teorik bölümünde dış duvar sistemi, dış duvar kaplamalarının işlevleri, özellikleri, uygulanma olanakları ve çeşitli türleri anlatılmış, detaylandırılma ilkeleri açıklanmıştır. Dersin uygulamalı bölümünde ise, Şekil 16'da gösterilen Altıncı Uygulama Çalışması sorusundaki 3 farklı dış duvar kaplamasına (büyük duvar kaplamalarına) ait belirtilen detayların çözümlenmesi ve çizilmesi istenmiştir. Bu sorudaki detaylar söz konusu kaplamaların yatay ve düşeydeki birleşimlerini içermektedir.

Altıncı Uygulama Çalışmasına katılan toplam 44 öğrencinin çizimleri, Tablo 6'da açıklanan kriterler kapsamında ve çizimlerde karşılaşılan hatalar doğrultusunda değerlendirilmiş, ortaya çıkan sonuçlar Şekil 17'de belirtilmiştir. Altıncı Uygulama Çalışmasında sınıfın genel başarı düzeyi Şekil 18'de gösterilmiştir.

\subsection{Yedinci Uygulama Çalışması}

06.04.2016 tarihinde gerçekleştirilmiş olan boyutlu taş plak, terracotta panel ve metal levha
Şekil: 14

Beşinci Uygulama Çalışmasında

belirlenen kriterlere göre hata yapan ögrencilerin sayısı.
Şekil: 15

Beşinci Uygulama çalışmasında aldıkları puanlara göre öğrencilerin sayısı.

64 Sayı 23, Mayıs 2017 
Şekil: 16

Altıncı Uygulama Çalışması.

Şekil: 17

Altıncı Uygulama Çalışmasında belirlenen kriterlere göre hata yapan ögrencilerin sayısı.

Şekil: 18

Altıncı Uygulama f̧alışmasında aldıkları puanlara göre öğrencilerin sayısı.
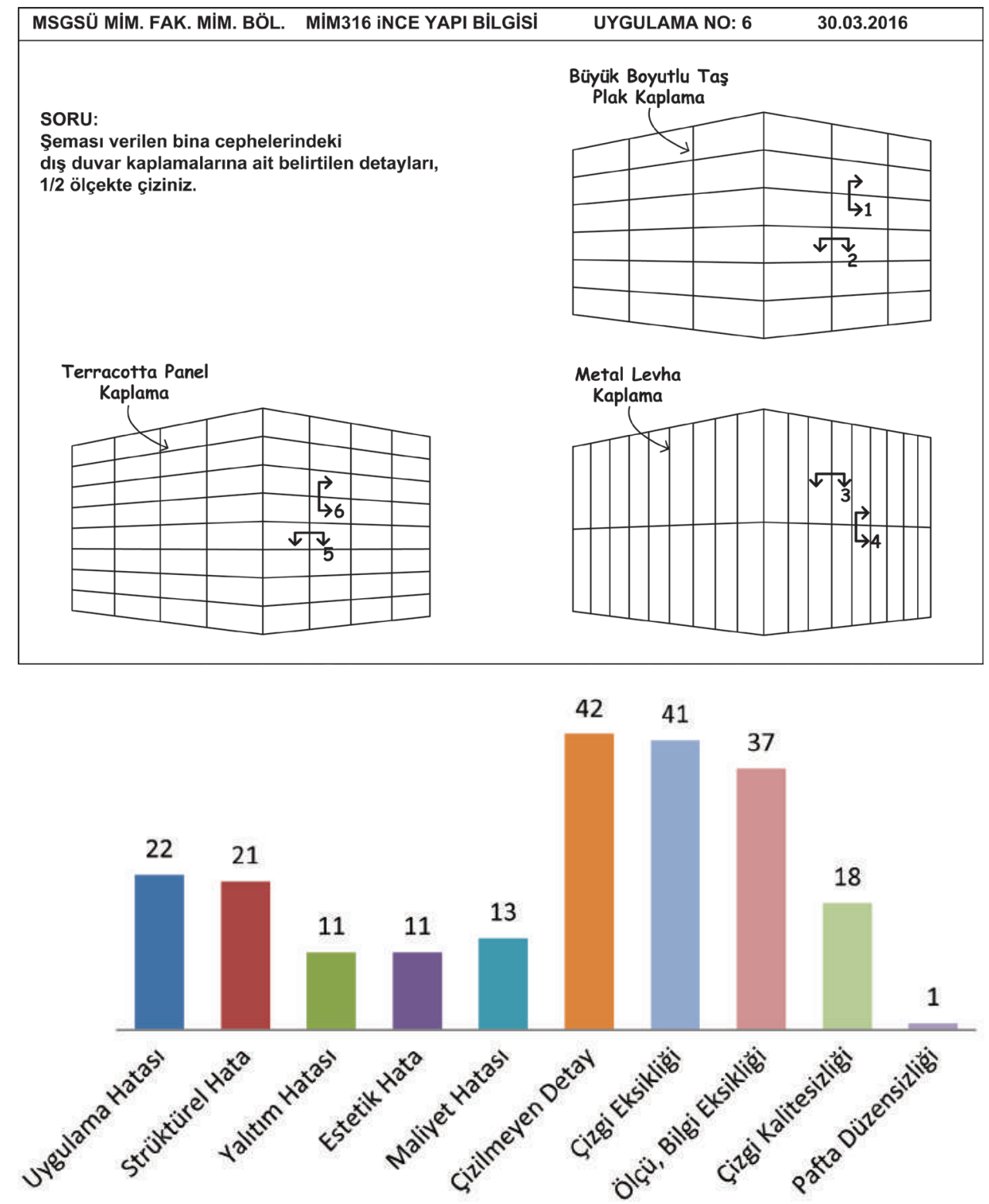

15

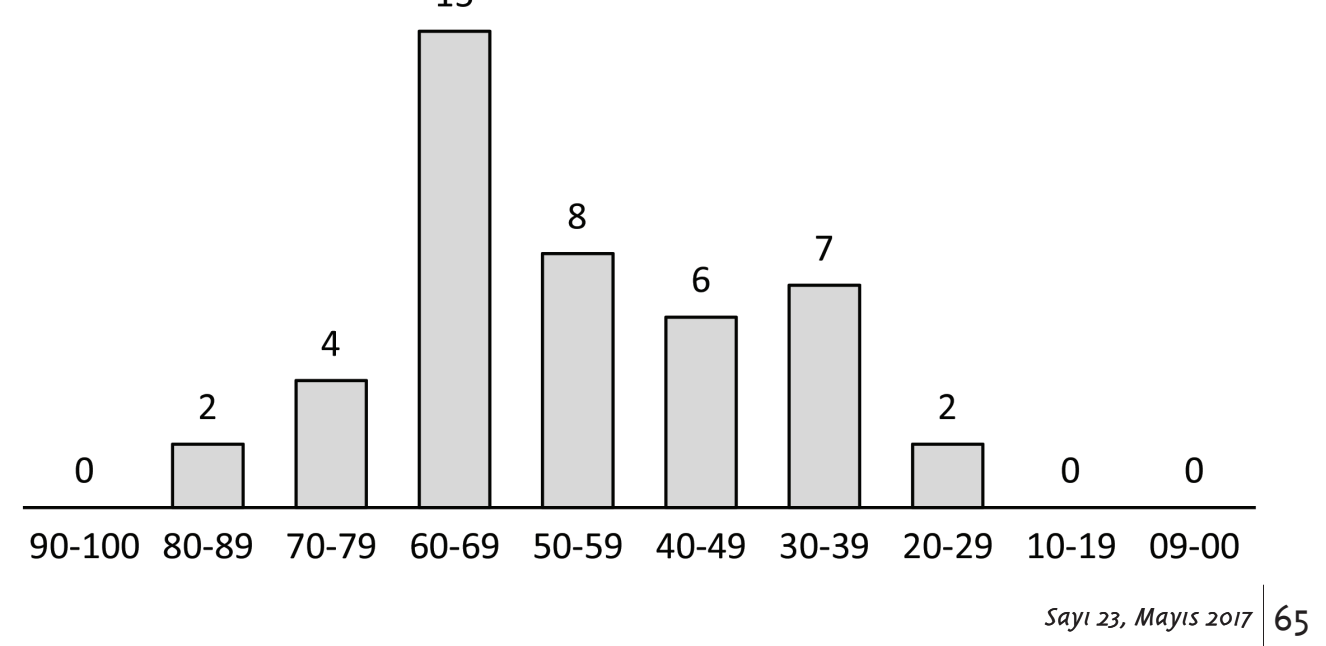


KRITERLER

\begin{tabular}{|c|c|}
\hline Uygulama Hatası & $\begin{array}{l}\text { *Kaplama altlık sisteminin (taşıyıcı ızgaranın) doğru kurgulanmaması } \\
\text { *Kaplama altlık sisteminin taşıyıcı sisteme doğru tespit edilmemesi } \\
\text { *Kaplama bileşenlerinin altlık sistemine doğru tespit edilmemesi }\end{array}$ \\
\hline Strüktürel Hata & $\begin{array}{l}\text { *Duvar kaplamasını taşıyan altlık sistemi boyutlarının hatalı } \\
\text { seçilmesi } \\
\text { *Taş plak kaplama boyutlarının hatalı seçilmesi } \\
\text { *Metal levha kaplama kalınlığının hatalı seçilmesi } \\
\text { *Terracotta panel kaplama kalınlığının hatalı seçilmesi }\end{array}$ \\
\hline Yalıtım Hatası & $\begin{array}{l}\text { *Bu uygulamada kaplama arkasındaki ısı yalıtım levhasının } \\
\text { gösterilmemesi istenmiştir } \\
\text { *Dış duvar kaplamalarının aralıklı birleşimlerinde derz dolgu } \\
\text { malzemesi kullanılmaması }\end{array}$ \\
\hline Estetik Hata & $\begin{array}{l}\text { *Duvar kaplama bileşenleri arasındaki birleşim noktalarının estetik } \\
\text { olmaması } \\
\text { *Duvar kaplama bileşenleri arasındaki derzlere uygulanan elastik } \\
\text { macunların estetik olmaması }\end{array}$ \\
\hline Maliyet Hatası & $\begin{array}{l}\text { *Duvar kaplama malzemelerinin gerekenden kalın seçilmesi } \\
\text { *Kaplama altlık sisteminde (taşıyıcı ızgarada) kullanılan profillerin } \\
\text { gerekenden büyük boyutta seçilmesi } \\
\text { *Taşıyıcı ızgara profillerini birbirine ve yapıya bağlayan tespit } \\
\text { elemanlarının gerekenden büyük boyutta seçilmesi }\end{array}$ \\
\hline Çizilmeyen Detay & $\begin{array}{l}\text { *istenen detaylardan en az birinin veya daha fazlasının tam olarak } \\
\text { çizilip bitirilmemesi }\end{array}$ \\
\hline Çizgi Eksikliği & *Detaylarda bazı bölümlerin ve çizgilerin çizilmemiş olması \\
\hline Ölçü, Bilgi Eksikliği & $\begin{array}{l}\text { *Ölçü ve bilgilerin her detayda belirtilmemiş veya eksik belirtilmiş } \\
\text { olması }\end{array}$ \\
\hline Çizgi Kalitesizliği & $\begin{array}{l}\text { *Plan, kesit ve görünüş çizimlerindeki çizgi türlerinin ve } \\
\text { kalınlıklarının çizim standartlarına uygun olmaması }\end{array}$ \\
\hline Pafta Düzensizliği & $\begin{array}{l}\text { *Öğrenci ismi, detay ismi, uygulama numarası vb. ifadelerin hiç } \\
\text { belirtilmemiş veya karmaşık olması }\end{array}$ \\
\hline
\end{tabular}

Tablo: 6

Altıncı Uygulama Çalışmasının değerlendirilmesinde kullanilan kriterler ve bu kriterler kapsaminda çizimlerde karşılaşılan hatalar. sekizinci dersin teorik bölümünde dış kap1 sistemi, dış kapıda duvar-kasa, kasa-cam, kasa-kanat, kanat-eşik ve kasa-ısı yalıtımlı sıva dış duvar kaplaması birleşim ilkeleri, ahşap dış kapı kanadı türleri, eşik türleri, ahşap dış kapı sisteminin detaylandırılma ilkeleri, üstü sabit camlı ve iki kanatlı dış kapı doğrama sistemlerinin detaylandırılma ilkeleri açıklanmıştır. Dersin uygulamalı bölümünde ise Şekil 19'da gösterilen Yedinci Uygulama Çalışması sorusundaki detayların plan-kesit-görünüş sisteminde çözümlenmesi ve çizilmesi istenmiştir. Bu uygulama çalışmasının konusu, tuğla diş duvar içinde düzenlenen, iki kanatlı ahşap dış kapı sisteminin detaylandırılmasıdır. Tuğla duvarın dış yüzü büyük boyutlu taş plak, iç yüzü ise sıva ile kaplıdır. Ahşap dış kapı kanatlarından geniş olanı çerçeveli tahtalı kanat, dar olanı ise çerçeveli camlı kanattır. Eşik ile iç ve dış döşeme kaplaması türleri öğrencinin seçimine bırakılmıştır.

Yedinci Uygulama Çalışmasına katılan toplam 49 öğrencinin çizimleri, Tablo 7'de açıklanan kriterler kapsamında ve çizimlerde karşılaşılan hatalar doğrultusunda değerlendirilmiş, ortaya çıkan sonuçlar Şekil 20'de belirtilmiştir. Yedinci Uygulama Çalışmasında sınıfın genel başarı düzeyi Şekil 21'de gösterilmiştir.

\subsection{Sekizinci Uygulama Çalışması}

13.04.2016 tarihinde gerçekleştirilmiş olan dokuzuncu dersin teorik bölümünde pencere sistemi, pencerelerde duvar-kasa, kasa-cam, kasa-kanat, kasa-denizlik ve kasa-taş plak dış duvar kaplaması birleşim ilkeleri, açılış şekline ve malzemelerine göre pencere türleri, denizlik türleri, ahşap sabit pencere, yan dönel pencere ve vasistas pencere sistemlerinin olum- 
Şekil: 19

Yedinci Uygulama Çalışması.

Sekil: 20

Yedinci Uygulama Çalışmasında belirlenen kriterlere göre hata yapan ögrencilerin sayısı.

Şekil: 21

Yedinci Uygulama Calısmasında aldıkları puanlara göre ögrencilerin sayısı.
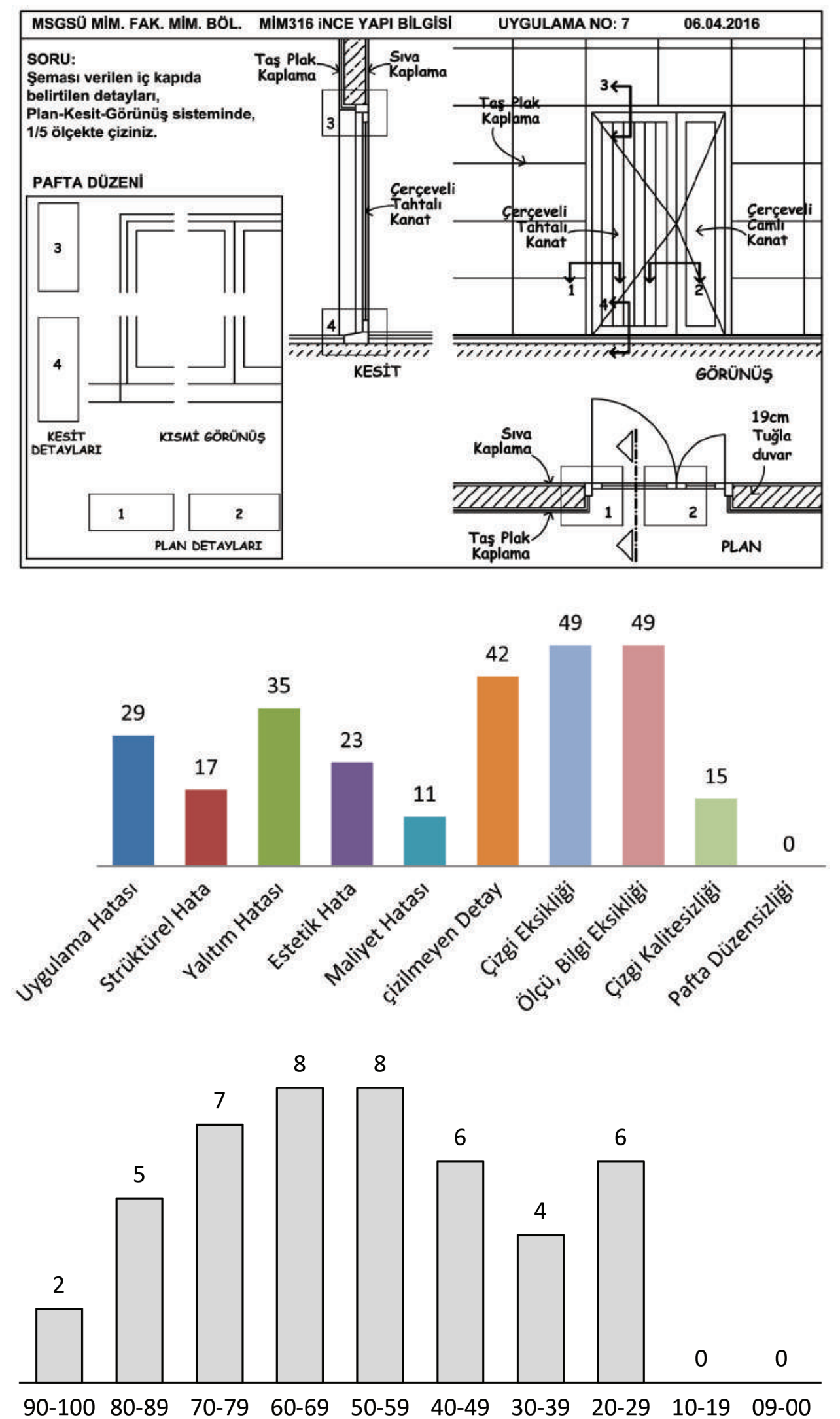
KRITERLER

KARŞILAŞILAN HATALAR

*Kasanın duvara tespitinin yapılamaması

*iki kanadın birleşim noktasında kullanılan pervazın hatalı tespit edilmesi

*Menteşelerin hatalı yerleştirilmesinden dolayı kanadın açılamaması

*Cam çıtalarının tespit edilebilmesi için yeterli mesafenin olmaması

*Kapı kanadı ile döşeme kaplaması arasında yeterli mesafenin

olmaması nedeniyle kapının yere sürtünmesi

Uygulama Hatası

*Çerçeveli tahtalı kanatta tahtaların serene bağlantısının hatalı yapılması

*Taş plak duvar kaplamasının montaj hataları nedeniyle uygulanamaması

*Taş plak kaplamaları taşıyan profillerin duvara hatalı tespit edilmesi

*Cam çıtalarının ters yöne takılması nedeniyle güvenlik sorunu

oluşması

*Montaj ve tespit hataları

*Kasanın duvara bağlantısının yapılmaması

*Taş plak kaplamaları taşıyan profil boyutlarının hatalı seçilmesi

Strüktürel Hata

*Taş plak duvar kaplaması kalınlığının hatalı seçilmesi

*Kanat çerçeve kesitinin hatalı boyutlarda seçilmesi

*Tabla malzemesi kalınlığının hatalı seçilmesi

*Dış duvarda ısı yalıtımı yapılmaması

*Kasa-duvar birleşiminde yalıtım yapılmaması

*Kanat-eşik birleşiminde yağmurluk yapılmaması ve hatalı

detaylandırma

*Kasa-kanat birleşiminde bini yapılmaması

Yalıtım Hatası

*Yağmurluğun altında damlalık yapılmaması

*Tahta birleşimlerinin hatalı detaylandırılması

* Kasada, içeri sızan suyu toplayacak oluk yapılmaması

*Taş plak dış duvar kaplamalarının aralıklı birleşimlerinde derz dolgu malzemesi kullanılmaması

*Dış kapı kanadı içinde ısı yalıtım malzemesi kullanılmaması

*Yağmurluk biçim ve boyutunun estetik olmaması

*Kasa ve kanat kesitlerinin gerekenden büyük boyutlarda seçilmesi

*Kasa-eşik birleşiminin estetik olmaması

Estetik Hata

*Cam tespit çıtalarının çerçeve hizasını geçerek dışarıdan algılanması

* Duvar kaplama bileşenleri arasındaki derzlere uygulanan elastik macunların estetik olmaması

*Kasa ve kanat kesitlerinin gerekenden büyük boyutlarda seçilmesi

*Yağmurluk kesitinin gerekenden büyük boyutlarda seçilmesi

*Taş plak dış duvar kaplamalarının gerekenden kalın seçilmesi

Maliyet Hatası

*istenen detaylardan en az birinin veya daha fazlasının tam olarak çizilip bitirilmemesi

Çizilmeyen Detay

Çizgi Eksikliği *Detaylarda bazı bölümlerin ve çizgilerin çizilmemiş olması

*ölçü ve bilgilerin her detayda belirtilmemiş veya eksik belirtilmiş olması

Ölçü, Bilgi Eksikliği

*Plan, kesit ve görünüş çizimlerindeki çizgi türlerinin ve kalınlıklarının çizim standartlarına uygun olmaması

*Öğrenci ismi, detay ismi, uygulama numarası vb. ifadelerin hiç belirtilmemiş veya karmaşık olması

lu-olumsuz özellikleri ve detaylandırılma ilkeleri açıklanmıştır. Dersin uygulamalı bölümünde ise Şekil 22'de gösterilen Sekizinci Uygulama Çalışması sorusundaki detayların plan-kesit-görünüş sisteminde çözümlenmesi ve çizilmesi istenmiştir. Bu uygulama çalışmasının konusu, tuğla dış duvar içinde düzenlenen, üstü vasistas kanatlı, altı yan dönel kanatlı ve sabit camlı ahşap pencere doğrama sisteminin detaylandırılmasıdır. Tuğla duvarın dış yüzü ısı yalıtımlı sıva, iç yüzü ise alçı levha ile kaplıdır. Denizlik türü öğrencinin seçimine bırakılmıştır.

Sekizinci Uygulama Çalışmasına katılan toplam 61 öğrencinin çizimleri, Tablo 8'de
Tablo: 7

Yedinci Uygulama çalışmasının değerlendirilmesinde kullanilan kriterler ve bu kriterler kapsaminda f̧izimlerde karşılaşılan hatalar. 
Şekil: 22

Sekizinci Uygulama Çalışması.

Şekil: 23

Sekizinci Uygulama Çalışmasında belirlenen kriterlere göre hata yapan ögrencilerin sayısı.
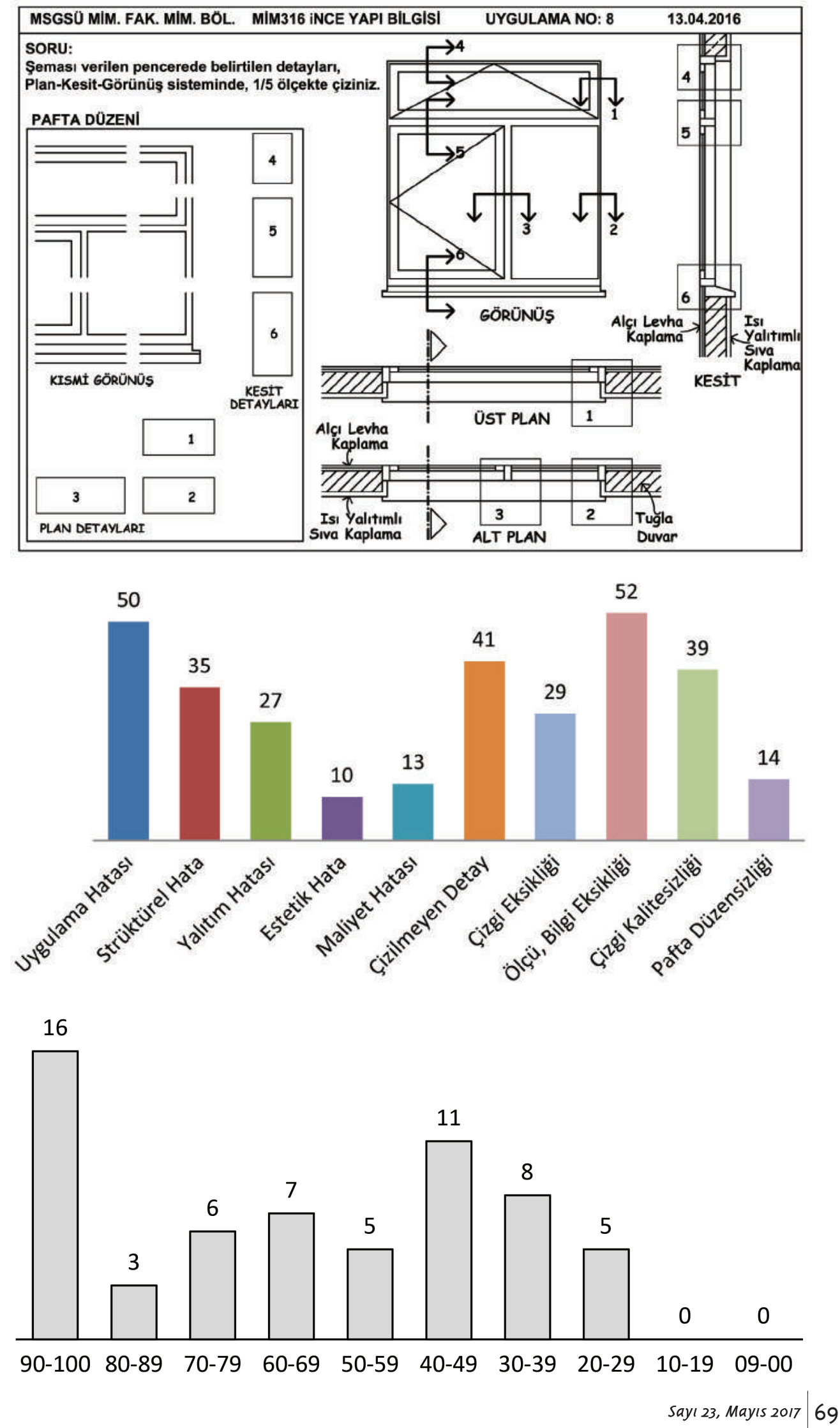


\begin{tabular}{|c|c|}
\hline KRITERLER & KARŞILAŞILAN HATALAR \\
\hline \multirow{5}{*}{ Uygulama Hatası } & *Kasanın duvara tespitinin yapılamaması \\
\hline & *Vasistas kanadın alt başlık kesitinin hatalı detaylandırılması \\
\hline & *Menteşelerin hatalı yerleştirilmesinden dolayı kanadın açılamaması \\
\hline & *Cam çıtalarının ters yöne takılması nedeniyle güvenlik sorunu oluşması \\
\hline & *Montaj ve tespit hataları \\
\hline \multirow{4}{*}{ Strüktürel Hata } & *Kasanın duvara bağlantısının yapılmaması \\
\hline & *Kasa ve kanat çerçeve kesitlerinin hatalı boyutlarda seçilmesi \\
\hline & *Alçı levha kaplamaları taşıyan lataların hatalı boyutlarda seçilmesi \\
\hline & *Alçı levha kalınlığının hatalı seçilmesi \\
\hline \multirow{8}{*}{ Yalıtım Hatası } & *Dış duvarda ısı yalıtımı yapılmaması \\
\hline & *Kasa-duvar arasında yalıtım yapılmaması \\
\hline & *Kanat alt başlığı ile kasa birleşiminde yağmurluk yapılmaması \\
\hline & *Kasa-denizlik birleşiminin hatalı detaylandırılması \\
\hline & *Kasa-kanat birleşiminde bini yapılmaması \\
\hline & *Yağmurluğun altında damlalık yapıımaması \\
\hline & *Kasada, içeri sızan suyu toplayacak oluk yapılmaması \\
\hline & $\begin{array}{l}\text { *Kasa alt başlığına, biriken suyu dışa akıtmak için metal boru } \\
\text { takılmaması }\end{array}$ \\
\hline \multirow{5}{*}{ Estetik Hata } & *Yağmurluk biçim ve boyutunun estetik olmaması \\
\hline & *Kasa ve kanat kesitlerinin gerekenden büyük boyutlarda seçilmesi \\
\hline & *Denizlik biçim ve boyutunun estetik olmaması \\
\hline & *Kasa-denizlik birleşiminin estetik olmaması \\
\hline & *Cam tespit çıtalarının çerçeve hizasını geçerek dışarıdan algılanması \\
\hline \multirow{2}{*}{ Maliyet Hatası } & *Kasa ve kanat kesitlerinin gerekenden büyük boyutlarda seçilmesi \\
\hline & *Yağmurluk kesitinin gerekenden büyük boyutlarda seçilmesi \\
\hline Çizilmeyen Detay & $\begin{array}{l}\text { *istenen detaylardan en az birinin veya daha fazlasının tam olarak çizilip } \\
\text { bitirilmemesi }\end{array}$ \\
\hline Çizgi Eksikliği & *Detaylarda bazı bölümlerin ve çizgilerin çizilmemiş olması \\
\hline Ölçü, Bilgi Eksikliği & $\begin{array}{l}\text { *Ölçü ve bilgilerin her detayda belirtilmemiş veya eksik belirtilmiş } \\
\text { olması }\end{array}$ \\
\hline Çizgi Kalitesizliği & $\begin{array}{l}\text { *Plan, kesit ve görünüş çizimlerindeki çizgi türlerinin ve kalınlıklarının } \\
\text { çizim standartlarına uygun olmaması }\end{array}$ \\
\hline Pafta Düzensizliği & $\begin{array}{l}\text { *Öğrenci ismi, detay ismi, uygulama numarası vb. ifadelerin hiç } \\
\text { belirtilmemiş veya karmaşık olması }\end{array}$ \\
\hline
\end{tabular}

açıklanan kriterler kapsamında ve çizimlerde karşılaşılan hatalar doğrultusunda değerlendirilmiş, ortaya çıkan sonuçlar Şekil 23’te belirtilmiştir. Sekizinci Uygulama Çalışmasında sınıfın genel başarı düzeyi Şekil 24’te gösterilmiştir.

\subsection{Dokuzuncu Uygulama Çalışması}

20.04.2016 tarihinde gerçekleştirilmiş olan onuncu dersin teorik bölümünde, ahşap düşey sürme pencere ve yatay eksenli pencere sistemlerinin olumluolumsuz özellikleri ve detaylandırılma ilkeleri, kasa-metal levha diş duvar kaplaması birleşim ilkeleri açıklanmıştır. Dersin uygulamalı bölümünde ise Şekil 25'te gösterilen Dokuzuncu Uygulama Çalışması sorusundaki detayların plan-ke- sit-görünüş sisteminde çözümlenmesi ve çizilmesi istenmiştir. Bu uygulama çalışmasının konusu, tuğla dış duvar içinde düzenlenen, üstü sabit altı hareketli kanatlı düşey sürme pencere doğrama sisteminin detaylandırılmasıdır. Tuğla duvarın dış yüzü düşey bant metal levha kaplama ile kaplıdır. Denizlik ve duvar iç kaplamasının türü öğrencinin seçimine bırakılmıştır.

Dokuzuncu Uygulama Çalışmasına katılan toplam 47 öğrencinin çizimleri, Tablo 9'da açıklanan kriterler kapsamında ve çizimlerde karşılaşılan hatalar doğrultusunda değerlendirilmiştir, ortaya çıkan sonuçlar Şekil 26'da belirtilmiştir. Dokuzuncu Uygulama Çalışmasında sınıfın genel başarı düzeyi Şekil 27'de gösterilmiştir.
Tablo: 8

Sekizinci Uygulama Çalışmasının değerlendirilmesinde kullanilan kriterler ve bu kriterler kapsaminda çizimlerde karşılaşılan hatalar 
Şekil: 25

Dokuzuncu Uygulama Çalışması

\section{Şekil: 26}

Dokuzuncu Uygulama Çalıșmasında belirlenen kriterlere göre hata yapan ögrencilerin sayısı

Sekil: 27

Dokuzuncu Uygulama Çalışmasında

aldıkları puanlara göre öğrencilerin sayısı
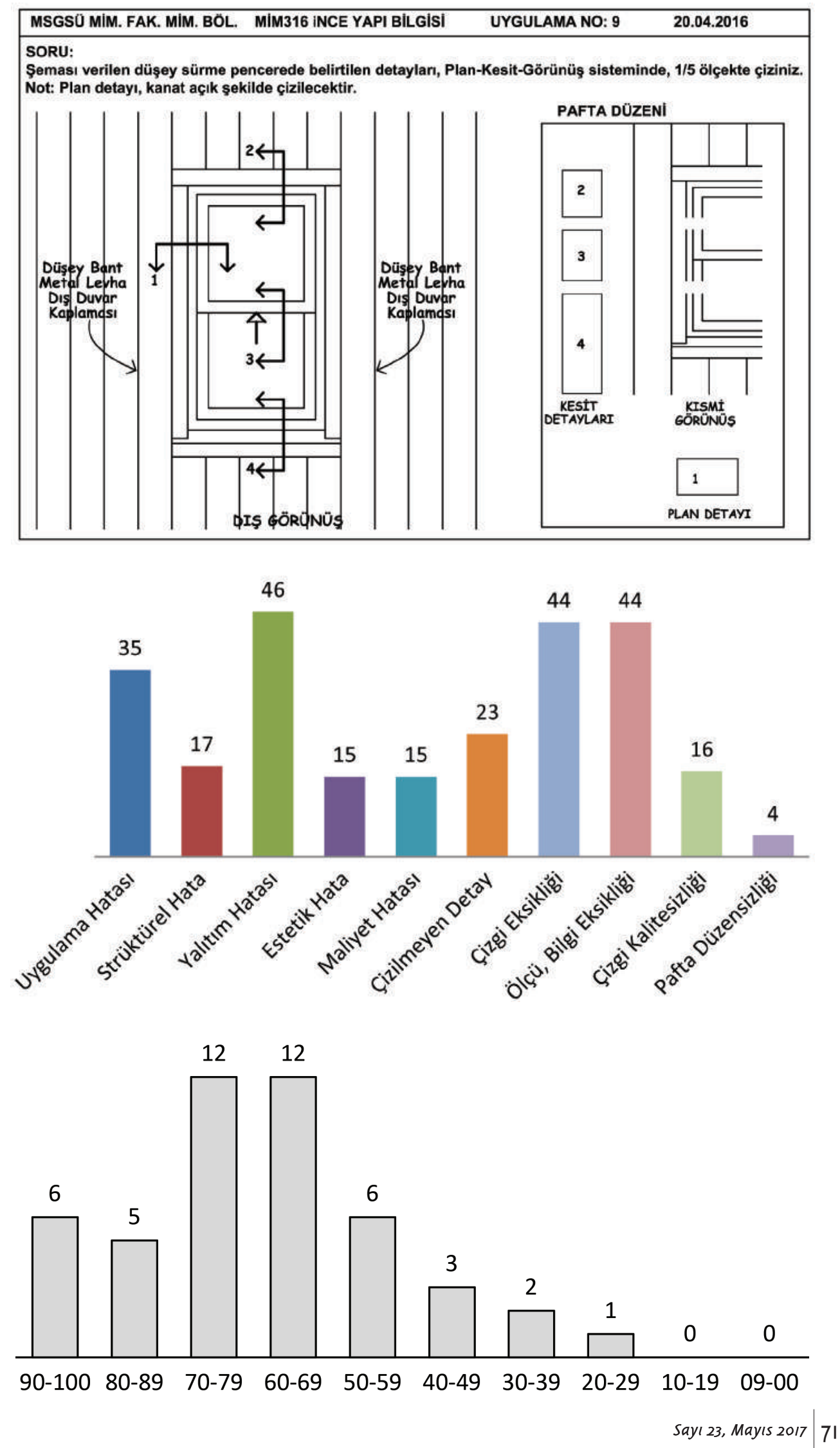


\begin{tabular}{|c|c|}
\hline KRITERLER & KARŞILAŞILAN HATALAR \\
\hline \multirow{7}{*}{ Uygulama Hatası } & *Kasanın duvara tespitinin yapılamaması \\
\hline & $\begin{array}{l}\text { *Kasada, iki kanadın birbirine çarpmasını önleyecek ara pervaz } \\
\text { yapılmaması }\end{array}$ \\
\hline & *Kasanın iç tarafında, hareketli kanadın devrilmesini önleyecek ve \\
\hline & hareketine olanak sağlayacak pervaz yapılmaması \\
\hline & *Metal levha dış duvar kaplama birleşimlerinin hatalı \\
\hline & detaylandırılması \\
\hline & *Montaj ve tespit hataları \\
\hline \multirow{4}{*}{ Strüktürel Hata } & *Kasanın duvara bağlantısının yapılmaması \\
\hline & *Kasa ve kanat çerçeve kesitlerinin hatalı boyutlarda seçilmesi \\
\hline & *Metal levha kaplamaları taşıyan profil boyutlarının hatalı seçilmesi \\
\hline & *Metal levha dış duvar kaplaması kalınlığının hatalı seçilmesi \\
\hline \multirow{10}{*}{ Yalıtım Hatası } & *Dış duvarda yalıtım yapılmaması \\
\hline & *Kasa-duvar arasında yalıtım yapıImaması \\
\hline & *Sabit kanadın kasaya bağlantısındaki hatalardan dolayı içeri su \\
\hline & girmesi *Kasa- \\
\hline & denizlik birleşiminin hatalı detaylandırılması \\
\hline & *Kesit çiziminde, iki kanat birleşiminde bini profili yapılmaması (hava \\
\hline & sızıntısı sorunu) ve esnek bant uygulanmaması (gürültü sorunu) \\
\hline & *Kesit çiziminde, kasa-kanat birleşiminde, kanadın oturacağı yüksek \\
\hline & Dir taban profill yapilmaması \\
\hline & $\begin{array}{l}\text { *Metal levha dış duvar kaplama birleşimlerinin hatalı } \\
\text { detaylandırılması *Sabit kanadın altında damlalık yapılmaması }\end{array}$ \\
\hline \multirow{4}{*}{ Estetik Hata } & *Kasa ve kanat kesitlerinin gerekenden büyük boyutlarda seçilmesi \\
\hline & *Denizlik biçim ve boyutunun estetik olmaması \\
\hline & *Kasa-denizlik birleşiminin estetik olmaması \\
\hline & *Cam tespit çıtalarının çerçeve hizasını geçerek dışarıdan algılanması \\
\hline \multirow{2}{*}{ Maliyet Hatası } & *Kasa ve kanat kesitlerinin gerekenden büyük boyutlarda seçilmesi \\
\hline & *Metal levha dış duvar kaplamalarının gerekenden kalın seçilmesi \\
\hline Çizilmeyen Detay & $\begin{array}{l}\text { *istenen detaylardan en az birinin veya daha fazlasının tam olarak } \\
\text { çizilip bitirilmemesi }\end{array}$ \\
\hline Çizgi Eksikliği & *Detaylarda bazı bölümlerin ve çizgilerin çizilmemiş olması \\
\hline Ölçü, Bilgi Eksikliği & $\begin{array}{l}\text { *Ölçü ve bilgilerin her detayda belirtilmemiş veya eksik belirtilmiş } \\
\text { olması }\end{array}$ \\
\hline Çizgi Kalitesizliği & $\begin{array}{l}\text { *Plan, kesit ve görünüş çizimlerindeki çizgi türlerinin ve kalınlıklarının } \\
\text { çizim standartlarına uygun olmaması }\end{array}$ \\
\hline Pafta Düzensizliği & $\begin{array}{l}\text { * Öğrenci ismi, detay ismi, uygulama numarası vb. ifadelerin hiç } \\
\text { belirtilmemiş veya karmaşık olması }\end{array}$ \\
\hline
\end{tabular}

\subsection{Onuncu Uygulama Çalışması}

27.04.2016 tarihinde gerçekleştirilmiş olan onbirinci dersin teorik bölümünde köşe doğraması, kör kasalı doğrama, döşemeye kadar indirilen doğrama ve karma doğramaların detaylandırılma ilkeleri açıklanmıştır. Dersin uygulamalı bölümünde ise Şekil 28'de gösterilen Onuncu Uygulama Çalışması sorusundaki detayların plan-kesit-görünüş sisteminde çözümlenmesi ve çizilmesi istenmiştir. $\mathrm{Bu}$ uygulama çalışmasının konusu, tuğla dış duvar içinde düzenlenen yatay eksenli pencere ve bunun altında döşemeye kadar indirilen yatay tahta örtülü sabit doğrama sisteminin detaylandırılmasıdır. Tuğla duvarın dış yüzü sıva kaplamalıdır. Eşik ve duvar iç kaplaması türü ise öğrencinin seçimine bırakılmıştır.

Onuncu Uygulama Çalışmasına katılan toplam 69 öğrencinin çizimleri, Tablo 10'da açıklanan kriterler kapsamında ve çizimlerde karşılaşılan hatalar doğrultusunda değerlendirilmiş, ortaya çıkan sonuçlar Şekil 29'da belirtilmiştir. Onuncu Uygulama Çalışmasında sınıfın genel başarı düzeyi Şekil 30'da gösterilmiştir.
Tablo: 9

Dokuzuncu Uygulama Çalışmasının değerlendirilmesinde kullanilan kriterler ve bu kriterler kapsaminda çizimlerde karşılaşılan hatalar. 
Şekil: 28

Onuncu Uygulama Çalışması.

Şekil: 29

Onuncu Uygulama çalışmasında belirlenen kriterlere göre hata yapan ögrencilerin sayısı.

Şekil: 30

Onuncu Uygulama çalışmasında aldıkları puanlara göre öğrencilerin sayısı.
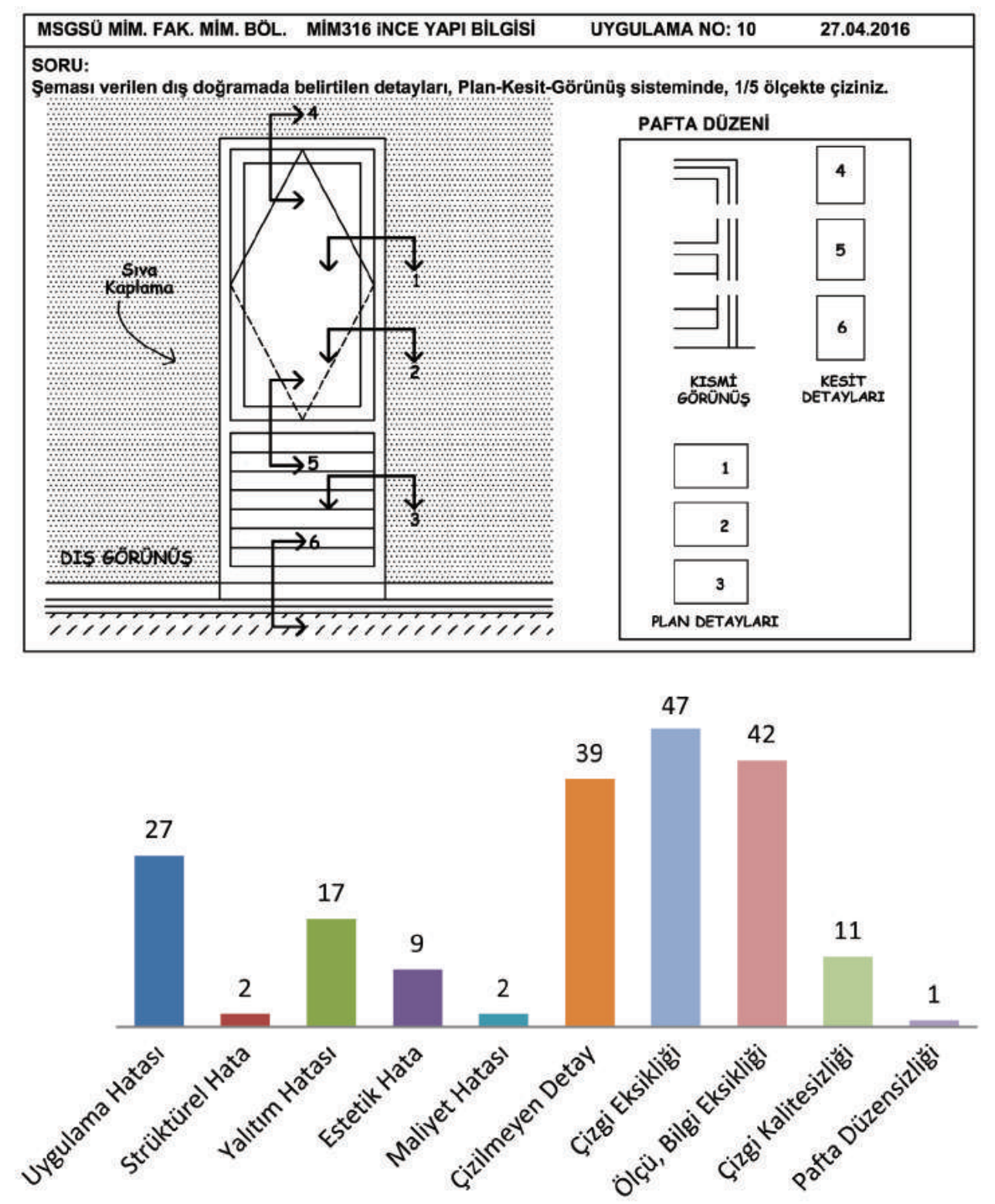

18

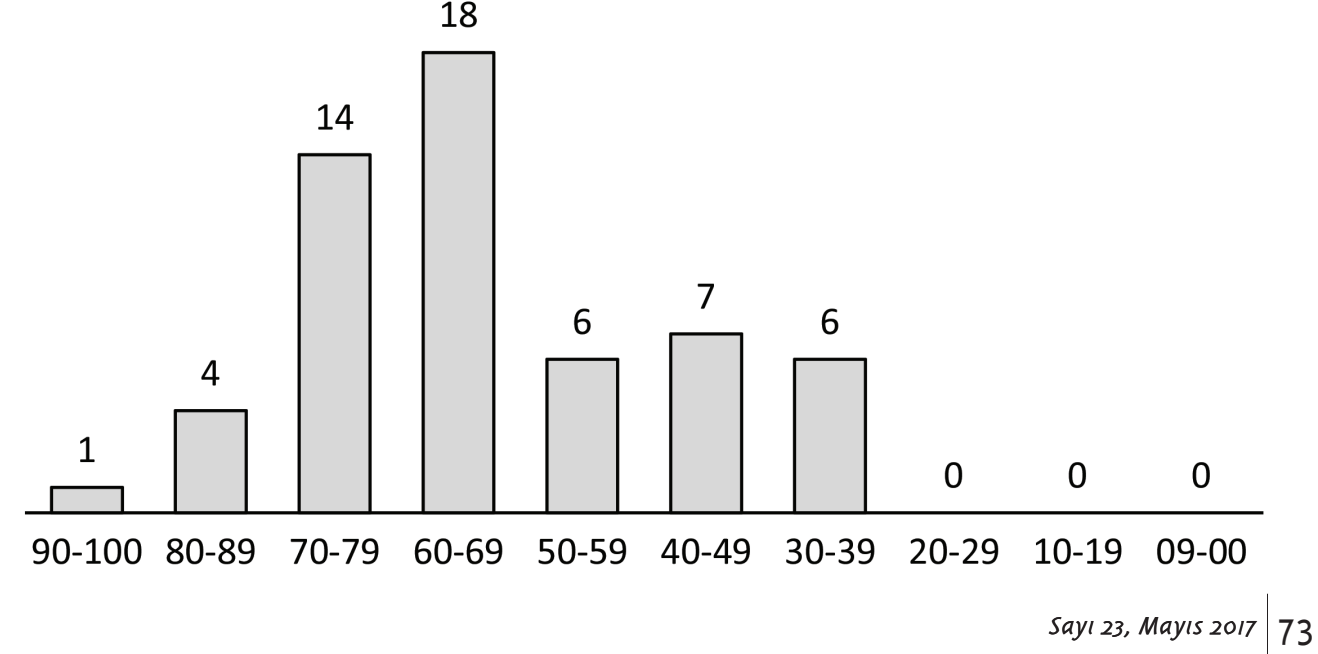




\begin{tabular}{|c|c|}
\hline KRITERLER & KARŞILAŞILAN HATALAR \\
\hline Uygulama Hatası & $\begin{array}{l}\text { *Kasanın duvara tespitinin yapılamaması } \\
\text { *Yatay eksenli doğramada kasa-kanat birleşiminde uygulanan } \\
\text { pervazların hatalı yerleştirilmesi } \\
\text { *Sabit doğrama içindeki tahtaların kasayla bağlantısının hatalı } \\
\text { yapılması }\end{array}$ \\
\hline Strüktürel Hata & $\begin{array}{l}\text { *Kasanın duvara bağlantısının yapılmaması } \\
\text { *Kasa ve kanat çerçeve kesitlerinin hatalı boyutlarda seçilmesi } \\
\text { *Sabit doğrama içindeki tahta kesit boyutlarının hatalı seçilmesi }\end{array}$ \\
\hline Yalıtım Hatası & $\begin{array}{l}\text { *Dış duvarda yalıtım yapılmaması } \\
\text { *Kasa-duvar arasında yalıtım yapılmaması } \\
\text { *Kasa-kant birleşiminde bini yapılmaması } \\
\text { *Sabit doğrama kasası ile eşik birleşiminde yağmurluk yapıımaması } \\
\text { ve hatalı detaylandırma } \\
\text { *Sabit doğrama içindeki tahta birleşimlerinin hatalı yapııması }\end{array}$ \\
\hline Estetik Hata & $\begin{array}{l}\text { *Kasa ve kanat kesitlerinin gerekenden büyük boyutlarda seçilmesi } \\
\text { *Eşik üstünde düzenlenen yağmurluğun biçim ve boyutunun estetik } \\
\text { olmaması } \\
\text { *Cam tespit çıtalarının çerçeve hizasını geçerek dışarıdan algılanması } \\
\text { *Yatay eksenli doğramanın kasa-kanat birleşiminin dış tarafında fuga } \\
\text { yapıımaması }\end{array}$ \\
\hline Maliyet Hatası & $\begin{array}{l}\text { *Kasa ve kanat kesitlerinin gerekenden büyük boyutlarda seçilmesi } \\
\text { *Sabit doğrama içindeki tahta kesit boyutlarının gerekenden büyük } \\
\text { boyutlarda seçilmesi }\end{array}$ \\
\hline Çizilmeyen Detay & $\begin{array}{l}\text { *istenen detaylardan en az birinin veya daha fazlasının tam olarak } \\
\text { çizilip bitirilmemesi }\end{array}$ \\
\hline Çizgi Eksikliği & *Detaylarda bazı bölümlerin ve çizgilerin çizilmemiş olması \\
\hline Ölçü, Bilgi Eksikliği & $\begin{array}{l}\text { *Ölçü ve bilgilerin her detayda belirtilmemiş veya eksik belirtilmiş } \\
\text { olması }\end{array}$ \\
\hline Çizgi Kalitesizliği & $\begin{array}{l}\text { *Plan, kesit ve görünüş çizimlerindeki çizgi türlerinin ve kalınlıklarının } \\
\text { çizim standartlarına uygun olmaması }\end{array}$ \\
\hline Pafta Düzensizliği & $\begin{array}{l}\text { *Öğrenci ismi, detay ismi, uygulama numarası vb. ifadelerin hiç } \\
\text { belirtilmemiş veya karmaşık olması }\end{array}$ \\
\hline
\end{tabular}

Tablo: 10

Onuncu Uygulama Çalışmasının değerlendirilmesinde kullanilan kriterler ve bu kriterler kapsaminda çizimlerde karşılaşılan hatalar.

\subsection{On Birinci Uygulama Çalışması}

04.05.2016 tarihinde gerçekleştirilmiş olan on ikinci dersin teorik bölümünde çatı sistemi, eğik ve düz çatı kaplama sistemleri, çatı kaplama türleri, pişmiş toprak kiremit kaplamaların, metal levha kaplamaların ve teras çatı kaplamalarının detaylandırılma ilkeleri, saçak detayları, mahya detayları, baca dibi detayları, oluk detayları açıklanmıştır. Dersin uygulamalı bölümünde ise Şekil 31'de gösterilen On birinci Uygulama Çalışması sorusundaki 5 adet nokta detayının çözümlenmesi ve çizilmesi istenmiştir. Bu detaylar, 1 ve 2 no'lu noktalarda marsilya tipi kiremit kaplamalı eğik çatı sisteminin ön ve yan saçaklarını, 3 ve 4 no'lu noktalarda metal levha kaplamalı eğik çatı sisteminin ön ve yan saçaklarını, 5 no'lu noktada ise çakıl kaplamalı düz çatı sisteminin dış kenarını içermektedir.

Ders sonunda öğretim elemanlarına teslim edilen On birinci Uygulama Çalışması çizimleri, düzeltmeler yapılarak hatalarını görmeleri için öğrencilere geri verilmiş, ancak zaman yetersizliği nedeniyle değerlendirilememiş ve puanlanamamıştır. Uygulama yapılmayan on üçüncü (son) derste ise giydirme cephe sistemi, giydirme cephe türleri ve giydirme cephelerin detaylandırılma ilkeleri açıklanmıştır.

\section{Değerlendirme}

Uygulama çalışması sonuçlarının değerlendirilmesi, tartışılması ve yorumlanması, hem teorik derslerin hem de uygulama çalışmalarının işleyişindeki eksik ve olumsuz tarafların açıklanması ve iyileştirmesi açısından önemlidir. 
Şekil: 31

On Birinci Uygulama Çalışması.

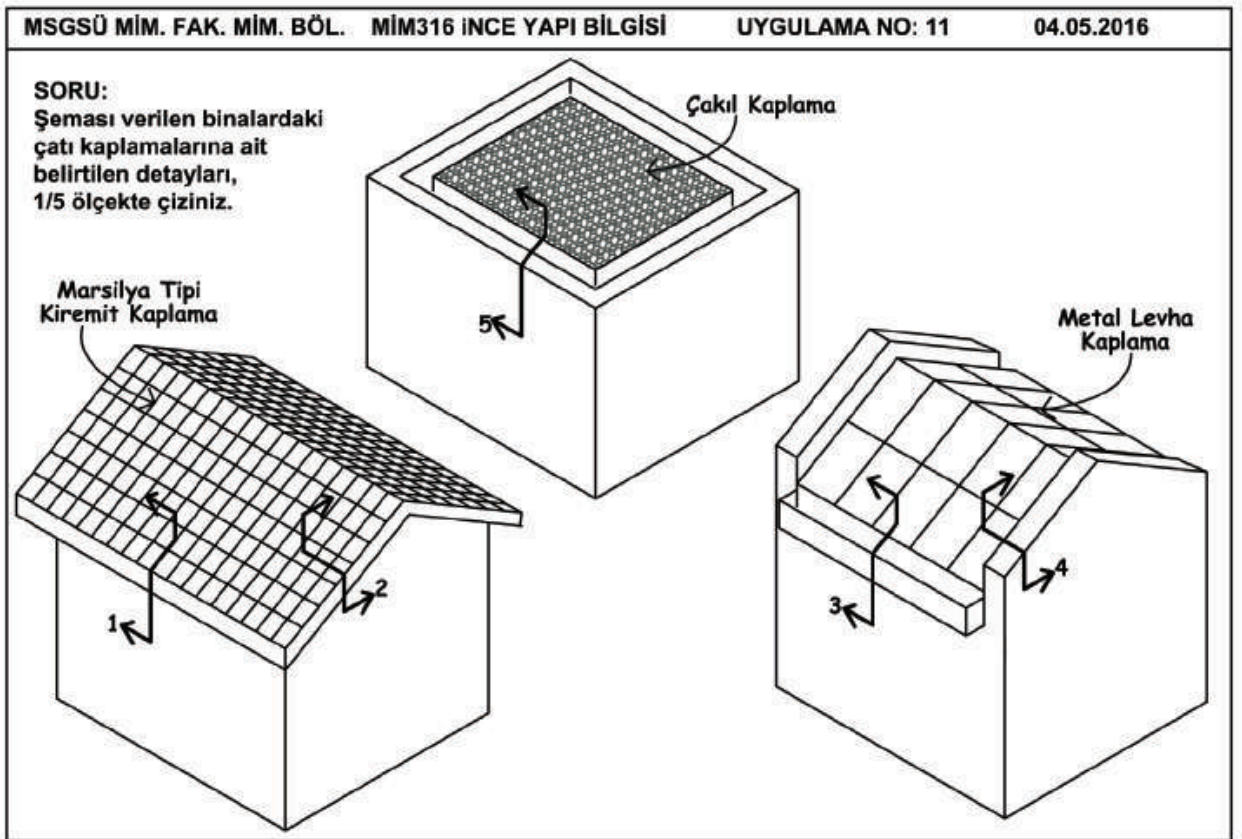

$\mathrm{Bu}$ çerçevede, sınıf genelinde başarı durumu belirlenmiş, katılanların yaklaşık yarısından daha fazlasının yaptığı önemli hatalar açıklanmış, hataların nedenleri konusunda öngörülerde bulunulmuş ve hataların azaltılması yönünde alınabilecek önlemler sunulmuştur.

\subsection{Birinci Uygulama Çalışmasının Değerlendirilmesi}

Birinci Uygulama Çalışmasına katılan 69 öğrenciden 58'i süpürgelik çözümlerinde uygulama hataları, 34 öğrenci süpürgelik biçim ve boyutlarında hatalı seçim, derz aralıklarının yetersiz yapılması, derz profili kullanılmaması gibi estetik hatalar yapmıştır. Derste anlatılmış olan bu tür konularda yapılan hataların nedenleri, öğrencinin derste anlatılan bilgileri tamamıyla öğrenememesinin yanı sıra, özensiz ve dikkatsiz çalışılmasına dayandırılabilir. Çünkü özensiz/dikkatsiz çizim, özellikle karmaşık biçimli parçalı bileşenlerin detaylandırılmasında çok fazla hata yapılmasına yol açmaktadır. Ayrıca, 21 öğrencinin çiziminde döşeme taşıyıcı sistemi (bileşenleri), bilgi yetersizliği nedeniyle ya hatalı çizilmiş veya eksik bırakılmış ve buradaki sorunların döşeme kaplama sistemine de yansıdığ 1 saptanmıştır. Bu da bize, öğrencilerin döşeme taşıyıcı sistemi konusundaki bilgilerinin daha ileri düzeyde olmasının, döşeme kaplaması detaylandırmasında önemli bir avantaj sağlayacağını göstermiştir. Bu uygulama çalışmasında, 69 öğrencinin tamamının çizimlerindeki detaylarda ölçü, bilgi eksikliği ve 51 öğrencinin detaylarında çizgi kalitesizliği saptanmıştır. Çizimlerin ilk uygulama çalışması olması, detay sayılarının ve kapasitelerinin öğrencinin çizim hızı açısından zorlayıcı olması, detaylandırmada öğrencilerin ölçü ve bilgi verilmesini önemsememeleri bu hataların yapılmasının önemli nedenleri olarak ileri sürülebilir. Yapılan değerlendirmede sınıf genelinde 40 puanın üzerinde not alan öğrenci sayısı 66 olmuştur.

\section{2. Íkinci Uygulama Çalışmasının Değerlendirilmesi}

İkinci Uygulama Çalışmasına katılan 70 öğrenciden 60'ının çizimlerinde, genellikle montaj ve tespit yöntemlerinin açıklanmaması, kaplamaların montajının yapılabilmesi için uygun lata düzeninin kurulmaması, kaplama dönüşlerinde hareket mesafesi bırakılmaması, tavan askı elemanlarının ters takılması gibi uygulama hataları görülmüştür. Bu tür hatalarının nedenleri genellikle, detayın 
bütün olarak algılanamamasına ve montajı yapılan bileşenlerin, uygulama koşullarının ve araçlarının tamamıyla anlaşılmamasına dayandırılabilir. 30 öğrencinin çizimlerinde süpürgelik biçim ve boyutlarında hatalı seçim, kaplama derz aralıklarının yetersiz yapılması, kaplamalarda derz profili ve gölge kanalı kullanılmaması gibi estetik hatalar saptanmıştır. Derste anlatılmış olan bu tür konularda yapılan hataların nedenleri, öğrencinin derste anlatılan bilgileri tamamıla öğrenememesinin yanı sıra, özensiz ve dikkatsiz çalışılmasına dayandırılabilir. Uygulama çalışmasında, 70 öğrencinin çizimlerindeki detaylarda ölçü, bilgi eksikliği ve çizgi kalitesizliği, 50 öğrencinin çiziminde pafta düzensizliği, 20 öğrencinin çiziminde ise çizilmemiş detaylar saptanmıştır. Öğrencilerin ölçü, bilgi verme konusundaki yetersizlikleri ve kesit-görünüş çizgi niteliklerini kalınlık farklılıkları ile ifade edememesinin detay çizimlerinde önemli bir hata olduğu öğrencilere özellikle anlatılmalı, bu hataların yapılmaması için, öğrenciler ölçü, bilgi verme ve çizgi kalınlıklarını ayarlama konusunda tekrar bilgilendirilmeli ve çizim standartlarını öğrenmeleri sağlanmalıdır. Bunların yanı sıra, uygulama çalışmasının başında öğrencilere verilen uygulama sorusunda çizim paftası düzeninin belirtilmesi, pafta düzensizliği hatalarının azalması ve çizim hızının artması için yararlı olabilir. Genelde hata sayısının fazla olmasına karşın yapılan değerlendirmelerde öğrenciler 40 puanın altında not almamıştır.

\section{3. Üçüncü Uygulama Çalışmasının Değerlendirilmesi}

Üçüncü Uygulama Çalışmasına katılan 62 öğrenciden 30'unun çizimlerinde montaj ve tespit yöntemlerinin açıklanmaması, kaplamaların montajının yapılabilmesi için uygun altlık düzeninin kurulmaması, kaplama dönüşlerinde hareket mesafesi bırakılmaması, asma tavan kaplaması ile duvar kaplamasının hatalı birleştirilmesi gibi uygulama hataları görülmüştür. $\mathrm{Bu}$ tür hatalarının nedenleri genellikle, detayın bütün olarak algılanamamasına ve montajı yapılan bileşenlerin, uygulama koşullarının ve araçlarının tamamıyla anlaşılmamasına dayandırılabilir. Bağlantı noktalarının detaylandırılmasında, uygulama ve montaj yönteminin anlaşılabilmesi için, çizimlerde tespit araçlarını mutlaka belirtilmesinin önemi öğrencilere anlatılmalıdır. 15 öğrencinin çiziminde, hafif çelik bölme duvarının tavan ve döşemeye tespitinde U profillerin kullanılmaması, ahşap kaplamaları taşıyan lata boyutlarının hatalı seçilmesi, duvar kaplamalarının kalınlıklarının hatalı seçilmesi, asma tavan askı elemanlarının taşıyıcılık işlevini yapamaması, ahşap kaplamalar arasında derz yapılmamas1 gibi strüktürel hatalar yapıldı̆̆ 1 tespit edilmiştir. 15 öğrenci bölme duvarı içinde yalıtım levhası çizmemiş, dolayısıyla yalıtım hatası yapmıştır. Derste anlatılmış olan bu tür konularda yapılan hataların nedenleri, öğrencinin derste anlatılan bilgileri tamamıyla öğrenememesinin yanı sıra, özensiz ve dikkatsiz çalışılmasına dayandırılabilir. Uygulama çalışmasında 50 öğrencinin detayları eksik çizdiği, 40 öğrencinin bazı detayları çizemediği, 56 öğrencinin çiziminde ise ölçü ve bilgi eksikliği saptanmıştır. Çizimin yetiştirilememesi olarak tanımlayabileceğimiz bu tür hataların nedenleri, dersin teorik bölümünde anlatılan konuların, dolay1sıyla sorulan detay sayısının kapsamlı ve fazla olmasına, seri ve hızlı çalışamayan öğrencilerin kısıtlı sürede detay çizimlerini tamamlayamamasına dayandırılabilir. $\mathrm{Bu}$ çalışmanın uygulama sorusunda çizim paftası düzeninin belirtilmesinin, pafta düzensizliği hatalarının azalmasında önemli derecede etki yaptığı söylenebilir. Genelde hata sayısının fazla olmasına karşın, bu uygulama çalışmasının not değerlendirmesinde 50 öğrenci 40 puanın üzerinde not almıştır.

\subsection{Dördüncü Uygulama Çalışmasının Değerlendirilmesi}

Dördüncü Uygulama Çalışmasının değerlendirme sonucunda, öğrencilere teorik derste bağlantı noktalarının montaj 
ve tespit yöntemleri dikkate alınarak çizilmesi konusunda yapılan uyarıların yararlı olduğu ve uygulama hatalarının azalmasını sağladığı saptanmıştır. Önceki hafta yapılan uygulama çalışmasıyla desteklenerek iyice öğrenilmiş olan bir konunun (hafifçelik bölme duvari), bu uygulama çalışması sorusunda da yer alması, çizimlerde uygulama hatalarının ve strüktürel hataların azalması için önemli bir neden olarak ileri sürülebilir. Derste anlatılmış olmasına karşın 27 öğrencinin bölme duvarı içinde yalıtım levhası çizmemiş olması, dolayısıyla yalıtım hatası yapması, öğrencinin derste anlatılan bilgileri tamamıyla öğrenememesinin yanı sıra, özensiz ve dikkatsiz çalışılmasına dayandırılabilir. Öğrencilere özellikle duvar detaylarında 1sı ve ses yalıtımı için önlemlerin alınmasının önemli olduğu, ancak bazı durumlarda, yalıtım malzemesi çiziminin detay çizimini karmaşıklaştırabileceği ve anlaşılmasını zorlaştırabileceği, bu nedenle yalıtım malzemesinin kısmen çizilmesinin veya var olduğunu belirtmek koşuluyla hiç çizilmemesinin gerekebileceği vurgulanarak açıklanabilir. Bu çalışmada pafta düzeninin soruda belirtilmesi, pafta düzeni konusunda hata yapılmamasını sağlamıştır. Dördüncü Uygulama Çalışmasına katılan 59 öğrenciden 48'inin detayları eksik çizdiği, 35'inin bazı detayları çizmediği, 47'sinin çiziminde ise detayda ölçü bilgi eksikliği tespit edilmiştir. Sorulan detay sayısının ve konu kapsamının çok geniş tutulmamasına karşın, bu tür çizimin yetiştirilememesi hatalarıyla karşılaşılma nedeni, öğrencinin yetersiz bilgisinin yanı sıra, çoğunlukla seri ve hızlı çalışma (uygulama çalışmasına erken başlama, çalışma sürecini verimli kullanma) becerilerinin kazanılmamış olmasına dayandırılabilir. Böyle bir becerinin kazanılabilmesi için, daha fazla uygulama çalışması yapılması ve uygulama çalışmalarının süresinin daha uzun tutulması yararlı olabilir. Genelde hata sayısı yüksek çıkmış, ancak değerlendirmelerde 40 puanın üzerinde not alan öğrenci sayısı 49 olmuştur.

\subsection{Beşinci Uygulama Çalışmasının Değerlendirilmesi}

Beşinci Uygulama Çalışmasına katılan 61 öğrenciden 50'sinin çiziminde uygulama hatası, 35'inin çiziminde strüktürel hata, 27'sinin çiziminde ise yalıtım hatası saptanmıştır. Uygulama hatalarını, çizimlerde menteşelerin kanatlarda doğru yerlere yerleştirilmemesi, kasanın duvara tespitinin yapılamaması, duvar ve tavan kaplamalarının montajının yapılamaması ve iki kanat birleşim çözümünde önce geniş kanadın açılamaması gibi sorunlar oluşturmaktadır. Bu hataların yapılması genellikle, dikkatsizlik, detaya bütüncül bakılmaması, montajı yapılan bileşenlerin yanı sıra uygulama koşullarının ve araçlarının tamamıyla anlaşılmaması gibi nedenlere dayandırılabilir. Çizimlerde karşılaşılan prese kanat çerçeve kesit boyutunun hatalı seçilmesi, alçı levha kaplamaları taşıyan lataların hatalı detaylandırılması ve alçı levha kalınlığının hatalı seçilmesi gibi strüktürel hataların, çoğunlukla öğrencinin bilgi yetersizliğinden kaynaklandığ 1 ileri sürülebilir. Çizimlerde ayrıca öğrencinin bilgi yetersizliği nedeniyle yapıldığı söylenebilecek, duvar-kasa arasının yalıtılmaması, prese kanat içinde yalıtım malzemesi kullanılmaması, kasa-kanat birleşiminde bini düzenlenmemesi gibi yalıtım hataları da görülmüştür. Bu uygulama çalışmasında, 41 öğrencinin bazı detayları çizmediği, 29 öğrencinin detayları eksik çizdiği, 52 öğrencinin detay çizimlerinde ölçü bilgi eksikliği, 39 öğrencinin çiziminde ise çizgi kalitesizliği belirlenmiştir. Bu tür çizimin yetiştirilememesi hatalarıyla karşılaşılma nedeni, öğrencinin yetersiz bilgisinin yanı sıra, seri ve hızlı çalışmamasına (uygulama çalışmasına erken başlamamasına, kısıtlı çalışma sürecini verimli kullanmamasına vb.) dayand1rılabilir. Yapılan değerlendirmede sınıf genelinde 40 puanın üzerinde not alan öğrenci sayısı 37 olmuştur.

\subsection{Altıncı Uygulama Çalışmasının Değerlendirilmesi}

Altıncı Uygulama Çalışmasına katılan 44 öğrenciden 22'sinin çiziminde uygulama 
hatas1, 21'inin çiziminde strüktürel hata görülmüştür. Uygulama hatalarını, kaplama bileşenlerinin altlık sistemine doğru tespit edilmemesi, kaplama altlık sisteminin doğru kurgulanmaması ve taşıyıcı sisteme doğru tespit edilmemesi gibi sorunlar oluşturmaktadır. Bu hataların yapılması, bilgi yetersizliği, detaya bütüncül bakılmaması, montaj1 yapılan bileşenlerin yanı sıra uygulama koşullarının ve araçlarının tamamıyla anlaşılmaması nedenlerine dayandırılabilir. Çizimlerde karşılaşılan altlık sistemi boyutlarının ve kaplama kalınlıklarının hatalı seçimi gibi strüktürel sorunların, çoğunlukla öğrencinin bilgi yetersizliğinden kaynaklandığı ileri sürülebilir. Bu uygulama çalışmasında, 42 öğrencinin bazı detayları çizmediği, 41 öğrencinin detayları eksik çizdiği, 37 öğrencinin çiziminde detayda ölçü bilgi eksikliği saptanmıştır. Çizimin yetiştirilememesi diye tanımladığımız bu tür hatalar, seri ve hızlı çalıșma beceriksizliğinin yanı sıra konunun şimdiye kadar çalışılan konulara benzememesi, dolayısıyla öğrencilerin soruya hemen uyum sağlayamamasından ve çizim ölçeğinin büyük olmasından kaynaklanmış olabilir. Yapılan değerlendirmede sınıf genelinde 40 puanın üzerinde not alan öğrenci sayısı 29 olmuştur.

\subsection{Yedinci Uygulama Çalışmasının Değerlendirilmesi}

Yedinci Uygulama Çalışmasına katılan 49 öğrencinin 29'unun çiziminde uygulama hatas1, 23'ünün çiziminde estetik hata görülmüștür. Çizimlerdeki uygulama hatalarının büyük bir kısmının montaj ve tespit sorunlarından oluşmuştur. $\mathrm{Bu}$ hatalar, geniş kapsamlı çalışma sorusunun, işlevleri yüksek derecede birbirine bağımlı bileşenlerden oluşan birleşim noktası detaylarını içermesi ve öğrencinin bu bileşenleri bütüncül bir yaklaşımla entegre edememesi nedeniyle ortaya çıkmış olabilir. Bileşen kesit boyutlarında ve birleşim yerlerinde karşılaşılan estetik hataları ise, öğrencinin detaylandırdı $\breve{g} 1$ bileşenleri bütün bir çerçeve perspekti- fiyle görmemesine bağlamak mümkündür. Değerlendirmede 42 öğrencinin bazı detayları çizmediği, 49 öğrencinin detayları eksik çizdiği, 49 öğrencinin çiziminde detayda ölçü bilgi eksikliği saptanmıştır. Çizimin yetiştirilememesi diye tanımladı$\breve{g} 1 \mathrm{~m} ı z$ hatalar bu uygulama çalışmasında çok fazla öğrenci tarafından yapılmıştır. $\mathrm{Bu}$ uygulama çalışmasında çok fazla hata yapılmasının ana nedeni, çalışma sorusunun geniş ve farklı konuları içermesine ve bazı öğrencilerin önceki derslerde anlatılan konularla yeni konular arasında ilişki kuramamasına ve entegrasyon oluşturamamasına dayandırılabilir. Çünkü dış duvar kaplamaları dersini öğrenememiş ve anlayamamış öğrencilerin çizimlerinde daha fazla hata yapıldığ 1 saptanmıştır. Bu sonuç, farklı zamanlarda anlatılan farklı ders konularını içeren bir detayda doğru entegrasyon çözümlerinin oluşturulabilmesi için, derslerin ve uygulama çalışmalarının önceki ders konularıyla ilişkili yürütülmesi, böylece birbirlerini etkileyen farklı konuların ve farklı sorunların bir arada ele alınması gerektiğini ortaya çıkartmıştır. Yapılan değerlendirmede sinıf genelinde 40 puanın üzerinde not alan öğrenci sayısı 30 olmuştur.

\subsection{Sekizinci Uygulama Çalışmasının Değerlendirilmesi}

Sekizinci Uygulama Çalışmasına katılan 61 öğrencinin 50'sinin çiziminde uygulama hatası, 35'inin çiziminde strüktürel hata, 27'sinin çiziminde yalıtım hatası görülmüştür. Çizimlerdeki uygulama sorunlarını montaj ve tespit hatalarının yanı sıra, menteşelerin doğru yerleştirilmemesi ve vasistas kanadın alt başlık kesitinin hatalı biçim ve boyutlarda tasarlanması oluşturmuştur. $\mathrm{Bu}$ hataların nedenleri, öğrencinin bilgi yetersizliğine ve kapsamlı bir doğrama sisteminde işlevleri yüksek derecede birbirine bağımlı bileşenlerden oluşan birleşim noktası detaylarını bütüncül bir yaklaşımla çözümleyememesine dayandırılabilir. Çizimlerde karşılaşılan, kasa ve kanat çerçeve kesit boyutlarının, alçı levha kaplama kalınlığının ve kaplamayı 
taşıyan lata boyutlarının hatalı seçilmesi gibi strüktürel sorunların, büyük oranda öğrencinin dikkatsizliğinden veya bu konulardaki bilgi yetersizliğinden kaynaklandığı söylenebilir. Çizimlerde ayrıca öğrencinin dikkatsizliği veya bilgi yetersizliği nedeniyle yapıldığg söylenebilecek, duvar-kasa arasının yalıtılmamas1, 1s1 yalıtımlı sıvanın hatalı detaylandırılması, kasa-kanat birleşiminde bini düzenlenmemesi, kasada içeri sızan suyun toplanarak dışarı akıtılmasını sağlayacak oluk yapılmaması, yağmurluk yapılmaması ve cam çıtalarının ters yöne takılması nedeniyle su sorunu oluşması gibi yalıtım hataları da görülmüştür. Bu uygulama çalışmasında 41 öğrencinin bazı detayları çizmediği, 29 öğrencinin detayları eksik çizdiği, 52 öğrencinin çiziminde detayda ölçü bilgi eksikliği, 39 öğrencinin detaylarında çizgi kalitesizliği saptanmıştır. Yapılan değerlendirmede sınıf genelinde 61 öğrenciden 37'si 40 puanın üzerinde not almıștır.

\subsection{Dokuzuncu Uygulama Çalışmasının Değerlendirilmesi}

Dokuzuncu Uygulama Çalışmasına katılan 47 öğrencinin 35'inin çiziminde uygulama hatası, 46'sının çiziminde yalıtım hatası görülmüştür. Çizimlerdeki uygulama sorunlarını montaj ve tespit hatalarının yanı sıra, kasada, iki kanadın birbirine çarpmasını önleyecek pervazların kullanılmaması ve metal levha dış duvar kaplama birleşimlerinin hatalı detaylandırılması oluşturmuştur. Bu hataların nedenleri, öğrencinin bilgi yetersizliğine ve birleşim noktalarını bütüncül bir yaklaşımla çözümleyememesine dayandırılabilir. Çizimlerde diş duvarda yalıtım yapılmaması, kasa-kanat ve kasa-denizlik birleşimlerinin hava ve su sızıntılarını engelleyebilecek biçimde tasarlanamaması ve metal levha dıș duvar kaplama birleşimlerinin hatalı detaylandırılması sonucunda içeri su girmesi gibi yalıtım sorunları görülmüştür. Çalışma sorusunun kendine özgü birleşimlere sahip farklı bir doğrama türünü içermesi ve dış duvar kaplamasının özel profiller ve çözümler gerektirmesi, yapılan hataların önemli nedenleri olarak ileri sürülebilir. Çizimlerde ayrıca 23 öğrencinin bazı detayları çizmediği, 44 öğrencinin detayları eksik çizdiği, 44 öğrencinin çiziminde detayda ölçü bilgi eksikliği saptanmıştır. Hata sayısının fazla olmasına karşın bu uygulama çalışmasında yapılan değerlendirmede sinıf genelinde 47 öğrenciden $41^{\prime} i 40$ puanın üzerinde not almıştır.

\subsection{Onuncu Uygulama Çalışmasının Değerlendirilmesi}

Onuncu Uygulama Çalışmasına katılan 69 öğrencinin 58'inin çiziminde uygulama hatası, 21'inin çiziminde strüktürel hata, 34'ünün çiziminde estetik hata görülmüştür. Çizimlerdeki uygulama sorunlarını, montaj ve tespit hatalarının yanı sıra, yatay eksenli doğramada kasa-kanat birleşiminde kullanılan pervazların hatalı yerleştirilmesi ve doğramadaki tahtaların kasayla bağlantı detaylarının hatalı çözümlenmesi oluşturmuştur. Strüktürel sorun olarak, kasa ve kanat çerçeve kesit boyutlarının zayıf seçilmesi gibi hatalarla karşılaşılmıştır. Çizimlerde ayrıca, kasa ve kanat kesit boyutlarının gerekenden daha büyük seçilmesi, eşik tasarımının kaba çözümlenmesi, cam çıtalarının çerçeve hizasını geçmesi, eksenli doğramada gölge kanallarının yapılmaması gibi estetik sorunlar da saptanmıştır. Kendine özgü birleşimlere sahip farklı doğrama türünü içeren böyle bir çalışma sorusunda yapilan bu hataların nedenleri genel olarak, öğrencinin bilgi yetersizliğinin yanı s1ra, kapsamlı (birbirinden farklı alt sistem kurgularına sahip) bir doğrama sistemine bütüncül yaklaşamayıp, birbiriyle ilișkili farklı noktaların detayları arasında doğru entegrasyonu sağlayamamasına dayandırılabilir. Bu uygulama çalışmasında 69 öğrencinin çiziminde detayda ölçü bilgi eksikliği, 51 öğrencinin çiziminde çizgi kalitesizliği, 39 öğrencinin çiziminde pafta düzensizliği saptanmıştır. Hata sayısının fazla olmasına karşın, yapılan değerlendirmede sinıf genelinde 69 öğrenciden 66's1 40 puanın üzerinde not almıștır. 


\section{Sonuçlar}

Bu çalışma sonucunda öncelikle, İnce Yapı Bilgisi dersinde hedeflenen Dersin Öğrenme Kazanımlarına ulaşabilmek için, teorik anlatımların uygulama ve çizim çalışmalarıyla desteklenmesinin, hatta uygulama çalışmalarına mümkün olduğunca uzun süre ayrılmasının, ayrıca değerlendirme sonuçlarının öğrencilerle paylaşılması ve tartışılmasının gerekliliği ve zorunluluğu ortaya çıkmıştır.

Çok fazla konuyu içeren İnce Yapı Bilgisi derslerinde, bir konudaki tüm detayların sıralanması yerine, birçok farklı konu için geçerli olabilecek detaylandırma ilkeleri ve kurallarının açıklandığı bir yöntem izlenmesi, hem ders anlatım zamanın daha etkin kullanılmasını, hem de verilen bilginin daha net anlaşılmasını ve daha kalıcı olmasını sağlamıştır.

2015-2016 Bahar Dönemi İnce Yap1 Bilgisi Dersinin bir dönem içinde yapılan tüm uygulama çalışmalarının değerlendirmesinde ortaya çıkan sonuçlar özet olarak Şekil 32'de açıklanmıştır. Bu genel değerlendirmede \%20 öğrenci çiziminde ölçü bilgi eksikliği, \%13 öğrenci çiziminde çizgi eksikliği, \%13 öğrenci çiziminde bazı detayların çizilmediği, \%10 öğrenci çiziminde ise çizgi kalitesizliği görülmüştür. Çizimin yetiştirilememesi olarak tanımlayabileceğimiz bu tür sorunlar uygulama çalışmalarında en fazla karşılaşılan hatalardır. Çizimin yetiştirilememesi sorunu çoğunlukla dersin teorik bölümünde anlatılan konuların, dolayısıyla

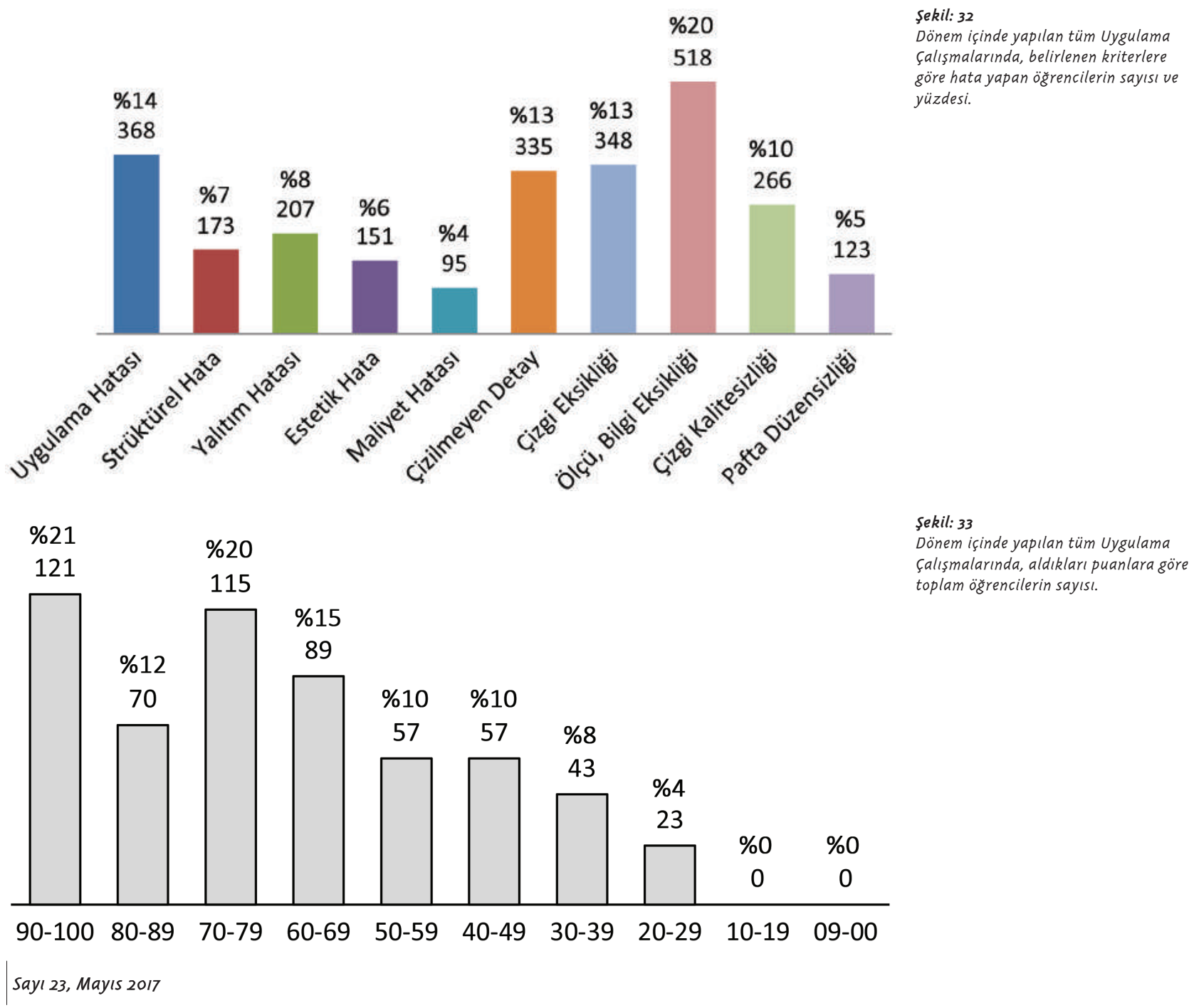


sorulan detay sayısının kapsamlı ve fazla, buna karşın uygulama çalışma süresinin az olmasından kaynaklanmaktadır. Ancak böyle bir sorun dersin kapsamına müdahale etmeden, öğrencilere seri ve hızlı çalışma (uygulama çalışmasına erken başlama, gerekli araç ve dokümanları etkin kullanma,

sorunlar karşısında ögretim elemanlarından yardım

alma, çalışma sürecini verimli kullanma vb.) becerisi kazandırılarak ve uygulama çalışma süresi uzatılarak çözülebilir. Ayrıca, uygulama çalışmalarında istenen verimin alınabilmesi için uygun bir çalışma ortamının (atölye kapasitesi, sağlık koşulları, çalışma koşulları vb. açısından) sağlanması da gerekmektedir.

Tüm uygulama çalışmalarının değerlendirmesine göre en s1k yapılan hatalardan biri de uygulanabilirlik sorunudur. Genel değerlendirmede \%14 öğrenci çiziminde uygulama hatası görülmüştür. Çizimlerdeki uygulama sorunlarının çoğunluğu montaj ve tespit hatalarından kaynaklanmaktadır. Bu tür hataların nedenleri genellikle, detayın bütün olarak algilanamamasina ve montaji yapılan bileşenlerin, uygulama koşullarının ve araçlarının tamamıyla anlaşılamamasına dayandırılabilir. Öğrencilere detaylandırma konularında kullanılan malzeme ve bileşenlerin uygulama ve montaj yerinde gösterilmesi, uygulama yöntemlerinin ve işlemlerinin izlettirilmesi ve detayların daha büyük bakış açısıyla plan-kesit-görünüş sisteminde bir bütün şeklinde çizdirilmesi ve algılatılması yararlı olacaktır. Ayrıca bağlantı noktalarının detaylandırilmasında uygulama ve montaj yönteminin anlaşılabilmesi için, çizimlerde tespit araçlarının mutlaka belirtilmesinin önemi öğrencilere anlatılmalıdır.

Tüm uygulama çalışmalarının değerlendirmesinde strüktürel hata, yalıtım hatas1, estetik hata, maliyet hatası, pafta düzensizliği gibi hataların daha az sayıda yapıldığı saptanmıştır. Bu sonuç, mimari detaylandırma dersine ilişkin teorik konuların genelde anlaşıldığını, ancak detay çizim becerisi için yukarıda açıklanan uygulama hatası ve çizimin yetiştiri- lememesi konularındaki yetersizliklerin karşılanması gerektiğini göstermektedir. Bir dönemlik uygulama çalışmalarının değerlendirmesinde, çeşitli hataların saptanmasına karşın öğrencilerin \% $\%$ ' $^{\prime} \mathrm{i}$ 50 puanın üzerinde not almıştır (Şekil 33)• 


\section{Kaynakça}

Allen, E. 2007. Architectural Detailing: Function, Constructibility, Aesthetics. John Wiley \& Sons.

Ballast, D.K. 2009. Architect's Handbook of Construction Detailing, John Wiley \& Sons.

Cheng, X. and Schierle, G. 2006. Architectural Detailing: A Teaching Methodology. Building Integration Solutions, Architectural Engineering Conference (AEI), pp. 1-15.

Eldem S.H. 1967. Yapı, Birinci Seri, İDGSA Yüksek Mimarlık Bölümü Yapı Kürsüsü Neşriyatı, İstanbul.

Emmitt, S., Olie, J. and Schmid, P. 2004. Principles of Architectural Detailing, Blackwell Publishing.

Frascari, M. 1984. The Tell-the-Tale Detail, VIA, no. 7, pp. 23-37.

Sahinler, O. ve K1z1l, F. 2004. Mimarlıkta Teknik Resim, Yap1 Endüstri Merkezi Yayınları, İstanbul.

Wakita, O. A and Linde, R.M. 1999. The Professional Practice of Architectural Detailing, John Wiley \& Sons. 